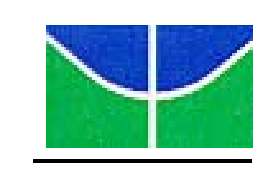

Universidade de Brasília (UnB)

Faculdade de Economia, Administração, Contabilidade e Ciência da

Informação e Documentação (FACE)

Programa de Pós-Graduação em Administração (PPGA)

IDALMO CARDOSO DA COSTA

\title{
Discurso Organizacional em Gestão de Pessoas em uma Organização Pública Federal
}




\section{Discurso Organizacional em Gestão de Pessoas em uma Organização Pública Federal}

Monografia apresentada ao Programa de PósGraduação em Administração (PPGA) da Faculdade de Economia, Administração, Contabilidade e Ciência da Informação e Documentação (FACE), da Universidade de Brasília (UnB) como requisito para a obtenção do grau de Especialista em Gestão Judiciária.

Orientador: Prof ${ }^{\circ}$ Marcus Vinicius Soares Siqueira 


\section{AGRADECIMENTOS}

Em primeiro lugar, muito obrigado a Deus pela vida e tudo que dela provém.

Ao professor Marcus Vinícius Soares Siqueira, que além de coordenar o curso se dispôs a orientar-me neste trabalho. Foi bastante enriquecedor tê-lo como orientador.

À todos os professores do Curso de Gestão de Pessoas, da UnB, pelo carinho, atenção e competência em disseminar conhecimento.

Aos trabalhadores administrativos e de apoio do PPGA-UnB, por sua presteza e disposição em ajudar.

Aos meus colegas e amigos de turma que dividiram comigo o prazer em aprender.

Às pessoas que participaram da pesquisa e se dispuseram espontaneamente a expressaram suas percepções sobre o seu trabalho. Muito obrigado!

Aos meus filhos Idalmo, Geovana e Débora Liz os quais me inspiram a querer melhorar sempre.

Aos amigos Adriana, Paulo, Hernando e Ana Lúcia, pelo apoio e incentivo constantes.

Especialmente a você, Danielle, pela paciência e em se resignar com minha ausência. Eu a amo profundamente. 
Mesmo que se chegue a uma organização i deal, se 0 modo de pensar e agir de cada indivíduo estiver errado, essa organização não poderá ser administrada com eficiência, e o resultado, infalivelmente, será a bancarrota...ou seja, deve-se considerar que o homem é o ponto principal, e a organização social, um ponto secundário.

Mokiti Okada 


\section{RESUMO}

O presente estudo teve como objetivo identificar os reflexos da transição do modelo burocrático para o modelo gerencial numa organização pública federal e analisar qual o discurso organizacional em gestão de pessoal está presente à luz do crescente gerencialismo e dos novos patamares de desempenho requeridos dos mesmos. Além de investigar a existência de ferramentas do modelo gerencialista na organização, identificar as conseqüências para os servidores e descrever como estão reagindo à transição. As relações estabelecidas para o estudo foram do modelo burocrático ao modelo gerencial, o gerencialismo e seus discursos e os discursos em gestão de pessoas. A pesquisa foi realizada com quatro profissionais ligados à gestão de pessoas na Instituição. O instrumento utilizado foi a entrevista semi-estruturada, composta por um roteiro de 12 questões baseadas em diversos aspectos, como por exemplo, conceitos e como percebem as formas de dominação, pressões sobre os servidores e resistências destes frente à transição, adaptação às novas ferramentas gerenciais e conseqüências para as condições de trabalho. As questões foram submetidas aos sujeitos de forma a deixá-los à vontade para se expressar da maneira mais conveniente e livre. Foi utilizado equipamento eletrônico de gravação das falas, a fim de preparar as transcrições para análise e categorização. Da análise resultaram três categorias definidas como 1 transição burocracia x modelo gerencial na ótica dos gestores de pessoas, 2 - gestão pública e privada: diferenças e semelhanças na percepção da gestão de pessoas e 3 resistências, pressões, discursos organizacionais em gestão de pessoas e conseqüências para os servidores públicos. Os resultados demonstraram a existência de diversas ferramentas do modelo gerencial sobrepostas à burocracias relacionadas ao referencial teórico estudado, os quais demonstrarão que a burocracia é vista como algo negativo; os gestores sabem diferenciar a gestão pública e privada; o discurso gerencial está presente na instituição e é aplicado por intermédio da sedução; a pressão via ferramentas gerenciais existem e as resistências idem; e o discurso em gestão de pessoas está bastante influenciado pela cultura do management, entre outras. Sugere-se, com base nos resultados, outros estudos que permitam aprofundar essas e outras questões relacionadas ao mundo do trabalho dos servidores públicos frente à transição.

Palavras-chave: Administração pública, burocracia, modelo gerencial, gerencialismo,. 



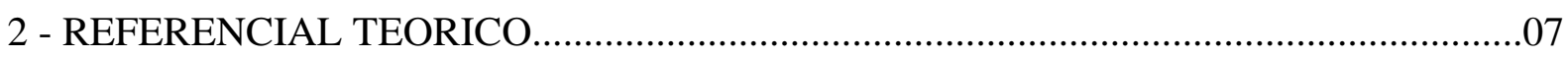

2.1- Do Modelo burocrático ao Modelo Gerencial na Administração................................07

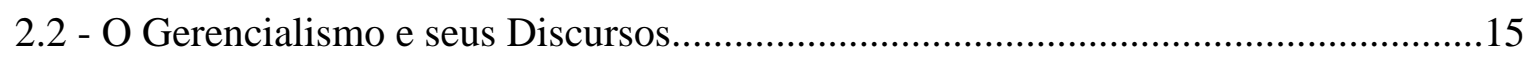

2.3 - Discurso Organizacional em Gestão de Pessoas........................................................22

2.4 - Modelos de gestão de Pessoas.................................................................................

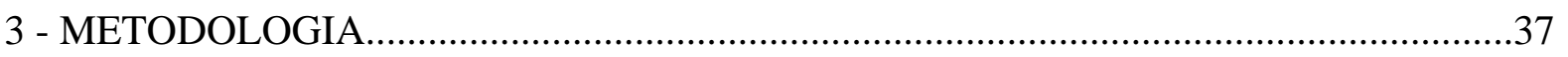

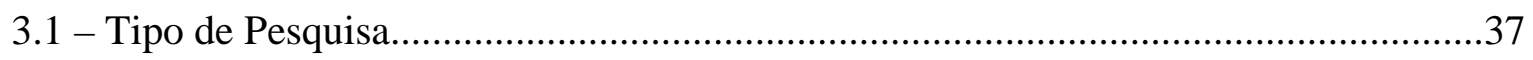

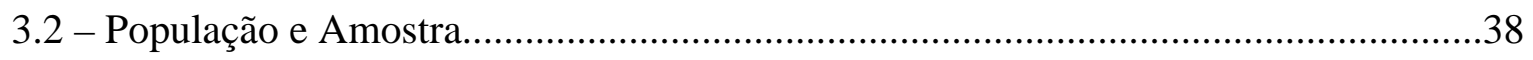

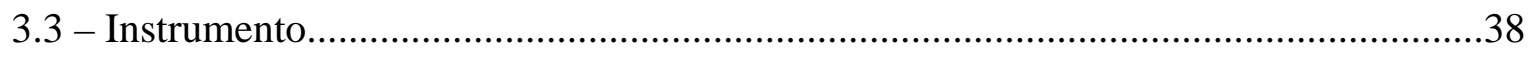

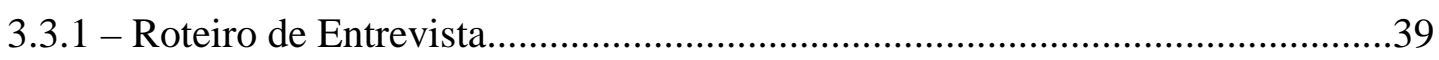

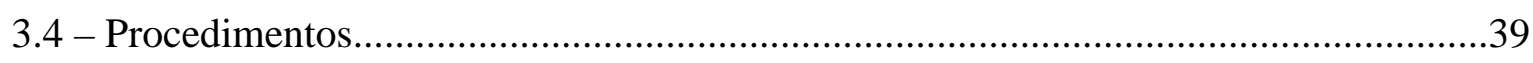

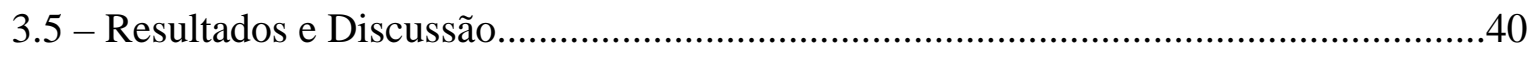

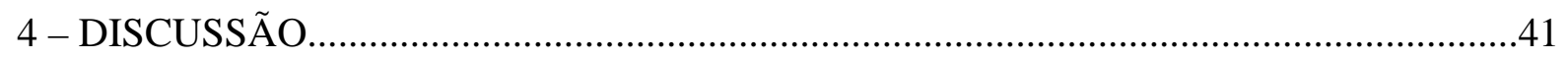

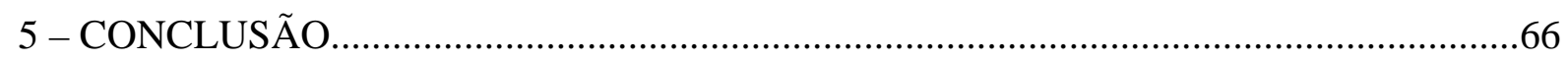

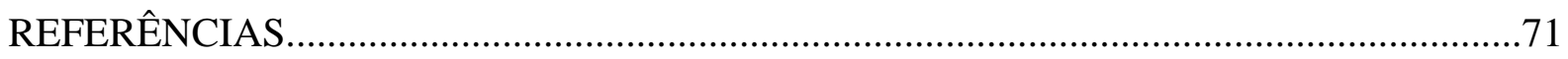




\section{1 - INTRODUÇÃO}

Com a demanda crescente em busca de justiça no Brasil, ou melhor, da Justiça, os Tribunais das instâncias de $1^{\circ}, 2^{\circ}$ e $3^{\circ}$ graus, das esferas estaduais e federais, especializadas ou não, infraconstitucionais ou constitucionais, estão sufocadas com a grande quantidade de processos que chegam a cada dia nos cartórios em busca de solução. Vemos a população clamar por rapidez nas respostas de seus pleitos. As cobranças por celeridade na Justiça são fundadas, uma vez que vemos casos que esperam por solução há mais de 20 anos.

Parece até que a administração pública no Brasil, incluído o Poder Judiciário, não acompanhou as diversas mudanças e transformações por que passou o mundo nos últimos 20 anos - mudanças inimagináveis tanto em tecnologia como em velocidade e quantidade de informação.

A sociedade deixou para trás as eras agrícolas e industriais e entrou na era da informação. Tão rica e complexa quanto o ser humano, a época atual para Vergara (2003) muda o eixo do poder, que deixa de pertencer aos músculos e vai para a mente e para o conhecimento.

A sociedade da informação trouxe consigo as complexidades das relações econômicas, políticas, sociais, tecnológicas, culturais e alterou valores pessoais, (VERGARA, 2003). A alta tecnologia tornou possível também a globalização que deixou o mundo sem fronteiras.

O arcabouço da Administração Pública no Brasil se desenvolveu e se estruturou tendo em vista a industrialização de nossa sociedade, ou seja, sob a égide da burocracia. Não acompanhou a velocidade das transformações.

Pelo contrário, as empresas privadas souberam tirar proveito da globalização e das complexidades advindas da enorme quantidade de informações propiciadas pela tecnologia. E com a evolução das práticas e ferramentas de gestão, as organizações deram um salto de qualidade e produtividade.

À globalização coube o papel de difundir mundo afora essa evolução, os novos paradigmas de competitividade, flexibilidade e, principalmente, os patamares de desempenho alcançados.

Durante nossa história, diversos movimentos tentaram sanar os problemas da administração pública. Atualmente no Brasil estamos vivendo a transição do modelo burocrático para o modelo gerencial. Este modelo baseado na eficiência vem pressionando a 
administração pública a alcançar os mesmos patamares de desempenho e produtividade da iniciativa privada.

Para a indústria do management ou gerencialismo, a adoção das ferramentas e práticas gerenciais tais como qualidade total, empowerment, gestão por competências, modelos de excelência, entre outros, tornaria a administração pública mais gerencial e os patamares de desempenho e produtividade factível nessa esfera.

Essa pressão vem de todos os lados. Basta ligarmos a televisão e a população é bombardeada com informações que denigrem a imagem da administração pública e dos servidores públicos, uma vez que são marajás e têm vários privilégios. Dentre os privilégios mais atacados estão a estabilidade e a aposentadoria integral com proventos da ativa.

O principal patrocinador dessa campanha é a própria indústria do management que quer, além de auferir lucros com vendas de livros, de consultorias, deseja também aumentar sua influência sobre os governos.

Outros incentivadores dessa campanha e interessado nessas mudanças são os governos, nacionais e subnacionais. Talvez acuados pela crise fiscal que assolou as contas públicas a partir dos anos de 1980 e impossibilitados de investir, enxergavam na flexibilização da estabilidade, podendo diminuir o contingente de servidores, e no corte na aposentadoria uma possibilidade de equilíbrio fiscal.

Na busca por melhorar a sua administração, a reforma do Judiciário volta à baila, suscitando discussões infindáveis e inconclusas. Através dela, o Judiciário busca resolver os problemas de celeridade na tramitação dos processos, a falta de transparência, a obsolescência administrativa, a dificuldade de acesso à justiça, a complexidade estrutural, a concentração de litigiosidade, a desarticulação institucional, além de outros obstáculos a uma justiça mais rápida no Brasil (RENAULT, 2005).

Como a situação do Judiciário é preocupante e exige uma resposta rápida, vários administradores estão importando tecnologias de gestão, inclusive de pessoas, prontas para o setor público, ou seja, estão, na prática, alterando a forma de dominação até então existente no serviço público do Brasil: da burocracia para o modelo gerencial.

Os reflexos dessa mudança, com a importação de ferramentas prontas sobre a Administração, são diversos, mas, para a presente pesquisa, os reflexos sobre a gestão de pessoas são o ponto, ou seja, o objetivo principal deste estudo é analisar qual o discurso organizacional em gestão de pessoal está presente numa organização pública federal à luz do crescente gerencialismo e dos novos patamares de desempenho requeridos dos mesmos. 
Como objetivos específicos, busca-se nesta monografia:

1 - Investigar a existência de ferramentas do modelo gerencialista na organização pesquisada;

2 - Identificar as conseqüências sobre os servidores; e

3 - Descrever como os servidores estão reagindo à transição da burocracia para o modelo gerencial;

Tal pesquisa se torna relevante neste momento que se comenta a Reforma do Poder Judiciário, haja vista não ter identificado na pesquisa bibliográfica realizada estudos que tratem do tema sobre as conseqüências da transição nem sobre a precariedade das condições de trabalho dos servidores públicos advindas com a reforma.

Subsidiariamente, acreditamos que surgirão questões relacionadas ao verdadeiro papel ou objetivos das entidades públicas: fornecer lucro ou qualidade de vida para a população; satisfazer os clientes ou dotá-los de cidadania; promover de fato a participação popular ou centralizar as decisões.

Todos esses temas estão relacionados com a formação de um Estado que promova a igualdade e não seja um mero fomentador de diferenças servindo apenas aos donos do capital. 


\section{2 - REFERENCIAL TEÓRICO}

\section{1- Do Modelo burocrático ao Modelo Gerencial na Administração}

O sistema burocrático proposto por Max Weber para combater o patrimonialismo, também denominado de dominação racional-legal, encontrou terreno fértil para se desenvolver com o processo de industrialização (VERGARA, 2003). Tem como características principais a formalidade, a impessoalidade e a administração profissional (PAULA, 2005) e se relaciona à divisão do trabalho, à hierarquia, à padronização, à impessoalidade, à meritocracia, ao administrador, ao contrato, à carreira, ao salário e à aposentadoria (VERGARA, 2003).

Alguns estudos sobre a reforma da administração pública têm afirmado que o antigo e ultrapassado modelo burocrático weberiano não é o mais adequado e que, para se alcançar eficiência, agilidade e flexibilidade na gestão pública, faz-se necessária a substituição desse modelo formalista, autocentrado e ineficiente por um novo modelo de administração, definido como gerencial (Presidência da República, 1995; BRESSER PEREIRA, 2001; CLAD, 2000; CUNILL, 2000 Apud AZEVEDO e LOUREIRO, 2003, p. 43).

Extraindo a afirmação de Bresser Pereira, teríamos a possibilidade de estabelecer que, para os defensores do modelo gerencial, este tem como características a eficiência, a agilidade e a flexibilidade.

Não seria prudente, a nosso ver, simplesmente mudar a concepção de dominação propiciada pela burocracia sem uma profunda reflexão, haja vista a burocracia se encaixar no Judiciário, pois essa função de Estado não pode ser dissociada da legalidade. Vale lembrar que em todos os atos judiciais, a legalidade deve ser observada, caso contrário correse o risco de nulidade; as regras devem ser formais, universais e impessoais, já que devem estar expressas, atingir a todos de forma equânime, independentemente de posição, classe ou qualquer outra questão pessoal.

Não é o caso de afirmar que a burocracia não tenha falha, pelo contrário, mas antes de tudo, os administradores que gerem pessoas têm de refletir profundamente sobre as conseqüências que essa mudança trará para os indivíduos nas instituições. Estes têm que ter em mente os conceitos tanto da burocracia quanto do modelo gerencial e, ainda, dos reflexos que surgirão.

Azevedo e Loureiro (2003), em seu estudo, afirmam que a burocracia em diversos países, inclusive no Brasil, nem sequer foi concretizada e que o clientelismo e patrimonialismo ainda hoje fazem parte da dominação. 
Matos e Lima (2007, p. 8), autores que defendem a Burocracia como forma de dominação, acreditam que

\begin{abstract}
as organizações modernas precisam ser racionais, eficientes e competentes, características que podem lhes ser fornecidas pela burocracia. Assim sendo, podemos afirmar que ocorreu, entre o tipo de dominação burocrática e as nascentes organizações modernas, eivadas dos princípios iluministas do racionalismo e do individualismo, uma atração, um tipo muito particular de relação dialética, em síntese, uma afinidade eletiva.
\end{abstract}

A afinidade eletiva, ou seja, uma atração mútua entre as organizações modernas e a administração burocrática seria, para esses autores, o modelo mais apropriado de dominação, já que se alcançaria com facilidade a eficiência.

Atualmente buscam-se todas as soluções no setor privado, desprezando a própria experiência vivida no setor público. Chanlat (2002) não acredita nesta solução e afirma que

contrariamente o que pensam certos críticos da burocracia, a ética do serviço público, que força o funcionário a deixar de lado suas posições pessoais, participa da consolidação das nossas democracias. A contrário, a introdução de formas empresariais de gestão no sistema público talvez seja uma ameaça a essa separação das ordens de existência, já que doravante todas as esferas serão reguladas pelo mesmo éthos, o dos negócios (CHANLAT, 2002, p. 6).

A origem do modelo gerencial é da época de Adam Smith. Em seu livro A Riqueza das Nações, de 1776, quando se consolidou o pensamento liberal que restringiu as funções do Estado à segurança, à justiça e aos serviços essenciais de utilidade pública, ele defendeu que o Estado não deveria interferir na economia, deixando ao mercado o papel de se organizar e harmonizar, visando alcançar a eficiência, a justiça e a riqueza (PAULA, 2005 apud CALGARO, 2007).

A nova administração pública tem suas origens na teoria da escolha pública e no neoliberalismo implementado por Margareth Thatcher, na Inglaterra, e Ronald Reagan, nos Estados Unidos, caracterizando-se "pelas medidas administrativas desenvolvidas visando à descentralização do aparelho do Estado, as privatizações das organizações estatais e a terceirização do serviço público" (CALGARO, 2007, p. 8).

A administração pública gerencial baseia-se principalmente no modelo inglês e no norte-americano, teve como ponto de partida o movimento internacional pela reforma do Estado nos anos de 1980, e tem seu projeto político na ênfase da eficiência administrativa. Além disso, propõe-se a ajustá-la estruturalmente seguindo as recomendações dos organismos internacionais e o movimento gerencialista. Suas dimensões estruturais são enfatizadas na 
gestão focada no econômico-financeiro e no institucional-administrativo, organiza o aparelho do Estado administrativamente, evocando a separação das atividades exclusivas e não exclusivas nos três níveis de Governo. Está aberto à participação social apenas em nível de discurso, o processo decisório é bastante centralizado, não dando oportunidade de participação à população. Por fim, enfatiza a adaptação das recomendações gerencialista para o setor público (PAULA, 2005).

O gerencialismo tem como pontos positivos "a clareza em relação à organização do aparelho do Estado e métodos e alguns destes métodos gerencialistas vêm melhorando a eficiência do setor público, especialmente no campo econômico financeiro" (PAULA, 2005, p. 178). Como pontos negativos, a autora aponta a centralização no processo decisório não estimulando a elaboração de instituições mais abertas à participação da sociedade e ainda o gerencialismo importou um modelo de reforma de gestão pronta, não construída no Brasil; logo, não observou as peculiaridades nacionais e preocupa-se mais com as dimensões estruturais do que com as dimensões sociais e políticas da gestão.

Paula (2005, apud CALGARO, 2007, p. 8) afirma que o "discurso utilizado pelos agentes da indústria do management consolidou o gerencialismo com base na crítica das organizações burocráticas, valorização da cultura do management e a transformação de práticas administrativas e gerenciais em modismos gerenciais".

A ascensão do gerencialismo vem orientando a administração pública para melhorar resultados e produtividade e as práticas utilizadas pela iniciativa privada para a obtenção de resultados econômicos e financeiros estão sendo transferidas para a gestão pública, tais como a avaliação por desempenho, o trabalho em equipe, os programas de excelência e a qualidade total (CALGARO, 2007).

Para Paula (2005) com o espaço alcançado pelo movimento gerencialista, este passou a recomendar a substituição do sistema burocrático pelo gerencial que se baseia nas crenças de que o progresso social decorre dos aumentos de produtividade. A produtividade aumenta com a aplicação de mais tecnologias. A aplicação das tecnologias se realiza por meio de uma força de trabalho disciplinada pela produtividade. O management - gerencialismo desempenha um papel crucial no planejamento e na implementação das melhorias necessárias à produtividade. Os gerentes têm o direito de administrar.

No gerencialismo, o Estado é feito para gerir a sociedade, e não "para garantir a segurança de todos, a igualdade de direitos, do desenvolvimento da democracia, do fato de que cada um possa ter um lugar sejam quais forem suas origens, suas competências, suas 
conviç̧ões e seus meios” e mais, em nome da eficácia, coloca-se “o Estado a serviço do desenvolvimento econômico” (GAULEJAC, 2007, p. 279).

Para Chanlat (2002, p.2) o gerencialismo, ou managerealismo, pretende ser um "sistema de descrição, explicação e interpretação do mundo a partir de categorias da gestão privada", ou seja, tudo, a partir da atual crise de descrédito do Estado, deverá ser guiado pelo mercado e, principalmente, visto pela ótica deste. Além disso, o que traz produtividade na visão dos defensores do gerencialismo trará progresso social.

Chanlat (2002) ainda descreve as manifestações dessa forma de entender o mundo a partir da gestão privada. Em primeiro lugar, o nível lingüístico que se expressa pelas palavras de gestão que invadiram os diálogos. Hoje não falamos mais administrar ou administrador, e sim gerir e management etc; Segundo, a influência crescente dos empresários e seus gestores e administradores, que a cada dia ganham mais poder e salários mais altos. O executivo tornou-se a figura central da sociedade contemporânea, em que brilha esse novo espírito do capitalismo; e o nível organizacional que, como já falado, passou a ser os óculos que devemos usar para enxergar o mundo dos negócios, incluídos aí os negócios públicos, haja vista que

as noções e os princípios administrativos oriundos da empresa privada (eficiência, produtividade, desempenho, competência, liderança empresarial, qualidade total, cliente, produto, marketing, excelência, reengenharia etc.) têm invadido amplamente as escolas, as universidade, os hospitais, as administrações, os serviços sociais, os museus, os teatros, as entidades sem finalidade lucrativa, até as igrejas (CHANLAT, 2002, p. 2).

Estamos vivenciando no Brasil a transição do modelo burocrático para o modelo gerencial no setor público. Chanlat (2002, p. 4) identificou alguns efeitos sobre a carga de trabalho, sobre o reconhecimento e sobre o amparo social dos servidores públicos.

Com a redução de pessoal e com os novos indicadores de desempenho e produtividade utilizados no setor privado, houve um aumento da carga de trabalho em geral, além de uma pressão maior por parte dos usuários sobre os empregados do serviço público que lidam diretamente com os usuários (CHANLAT, 2002, p. 4).

Existe uma tendência pelo aumento da responsabilidade e pela imputabilidade do servidor público. Esse desejo gerencial aumenta as contradições e incoerências da realidade, haja vista que, apesar do gerencialismo, a hierarquia continua sempre presente e a autonomia bastante reduzida. Com a chegada de novas tecnologias da informação, o sentimento de controle da hierarquia aumentou (CHANLAT, 2002). 
Sobre esse paradoxo, hierarquia x autonomia, Enriquez (1997a, p. 19), em seu estudo O Indivíduo Preso na Armadilha da Estrutura Estratégica, afirmou que jamais o "indivíduo esteve tão encerrado nas malhas das organizações (em particular, das empresas) e tão pouco livre em relação ao seu corpo, ao modo de pensar, a sua psique".

Em outro estudo, Os Desafios Éticos nas Organizações Modernas, Enriquez (1997b, p. 12), completa a afirmação anterior quando diz que

de fato, muitas vezes, quando os homens nas organizações são designados como
responsável isto significa somente que eles são obrigados a prestarem contas de suas
decisões do bom andamento dos serviços a seus superiores e de aceitar o julgamento
dos mesmos. Ser responsável é então, ser o alvo de toda sanção, vendo-se ao mesmo
tempo afastado de qualquer possibilidade de avaliar sua própria ação. Compreende-
se muito bem por que certas pessoas não assumem ou mesmo fujam das
responsabilidades que lhes são confiadas, pois elas captaram bem a 1ógica da
organização: todo responsável é um constante suspeito é um provável culpado.

Sobre o reconhecimento, Chanlat (2002) afirma que, no decorrer dos últimos 20 anos, os empregados do setor público sofrem fortemente os efeitos dos discursos sobre sua suposta ineficiência, chegando alguns a esconderem a condição de funcionário público em eventos sociais por vergonha. O funcionário público seria objeto de escárnio da população.

Como afirma Faria, Schimit e Meneguetti (2007, p. 71), "um dos elementos centrais do mundo exterior aos indivíduos é a aceitação social. A identidade de um sujeito é afirmada ou negada conforme sua legitimação". Os funcionários públicos estão no momento sem o necessário para desempenhar suas funções, sem identidade e sem aceitação social.

Diante da responsabilização e aumento da carga de trabalho e da falta de aceitação perante a sociedade, além do paradoxo citado, os gestores percebem ou não se houve de fato aumento da pressão, da responsabilização e do aumento da carga de trabalho, como observado por Chanlat (2002).

Embora esta pesquisa tenha como foco principal os reflexos sobre os servidores públicos, principalmente os expostos acima por Chanlat (2002), existem várias outras conseqüências, inclusive para a democracia, haja vista que no modelo gerencial a importância recai para "soluções técnicas, a administração enfatiza mais os aspectos instrumentais da gestão do que os sociopolíticos: focaliza-se a eficiência dos processos gerenciais e delega-se a análise dos seus impactos para a ciência política” (PAULA, 2005 P. 21).

Os resultados que o gestionário busca se referem à dimensão econômicofinanceira, relacionada às questões decorrentes da gestão fiscal, tributária e monetária e à dimensão institucional-administrativa, relacionada à organização dos órgãos públicos e 
dificuldades de planejamento, direção e controle das ações estatais e dos servidores públicos em detrimento à dimensão sociopolítica, que trata da relação do Estado com a sociedade, incluídos neste tópico os direitos dos cidadãos e sua participação na gestão pública, conclui Paula (2005).

De acordo com Paula (2005), é de fundamental importância para a consolidação da democracia e para o interesse público que a administração e a política caminhem juntas, posto que a gestão do setor privado se volta predominantemente para os resultados e, com a nova administração pública baseada no modelo gerencial, "mantém a dicotomia entre a política e a administração, pois adere a uma dinâmica administrativa que reproduz a lógica centralizadora das relações de poder e restringe o acesso dos cidadãos ao processo decisório” (PAULA, 2005 p. 21).

O fato é que o movimento gerencialista hoje se encontra tão imbricado no tecido social que não podemos ignorá-lo, sendo que as organizações empresariais são responsáveis pelas posições de destaque na sociedade, no processo de socialização dos indivíduos, tanto na educação, como nas aquisições de habilidade e experiências (PAULA, 2005), que se tornou difícil resistir ao poderoso marketing a seu favor.

A divulgação dos valores, símbolos, linguagens e crenças do gerencialismo vêm sendo transmitidas sistematicamente pela mídia, justamente porque, além dos executivos necessitarem de autopromoção, vangloriando-se dos seus feitos, precisam também de propaganda para encontrar novos mercados para suas idéias. "Nos Estados Unidos, o movimento gerencialista também contribui para criar um imaginário organizacional e social: a cultura do management" (PAULA, 2005, p. 57).

A cultura do management se caracteriza pela produção de artefatos como livros, revistas e outros objetos de consumo presentes no mundo dos negócios e pode ser definida como um conjunto de pressupostos compartilhados pelas empresas como

\footnotetext{
a crença numa sociedade de mercado livre; a visão do indivíduo como autoempreendedor; o culto da excelência como forma de aperfeiçoamento individual e coletivo; o culto de símbolos e figuras emblemáticas, como palavras de efeito (inovação, sucesso, excelência), "gerentes heróis"; e a crença em tecnologias gerenciais que permitem racionalizar as atividades grupais (PAULA, 2005, p. 57).
}

Essa faceta das organizações em promover ou criar culturas através da mídia também foi observada por Freitas (2000), que percebeu que as empresas, aproveitando-se da crise do Estado-Providência e a confirmação do capitalismo como a única opção capaz de desenvolvimento, buscam a supremacia total e legitimação social construindo "para e de si uma auto-imagem grandiosa, que vai enraizar-se num imaginário próprio, que é repassado não 
apenas para os seus membros internos, mas também para a sociedade" (FREITAS, 2000, p. 10).

Além disso, no contexto das rápidas e complexas transformações econômicas, sociais e culturais, as grandes empresas souberam tirar proveito da velocidade das mudanças advindas da era tecnológica e passam a exercer poder cada vez maior e mais influência sobre os governos, indicando os rumos da economia e da vida social (SIQUEIRA, 2006).

Outro autor, Vincent de Gaulejac (2005), vê que as principais características do gerencialismo estão focadas nos objetivos financeiros, na produção de adesão e na mobilização psíquica, e que a evolução do Taylorismo deságua no gerencialismo. O Taylorismo era

centrado sobre a canalização da atividade física, tornando os corpos úteis, dóceis e produtivos. Atuando sobre o controle do tempo e pelo quadriculamento do espaço enquanto que o poder gerencialista preocupa-se em transformar a energia libidinal em forca de trabalho. Passa-se do controle das minúcias do corpo para a mobilização psíquica a serviço da empresa. A repressão é substituída pela sedução, a imposição pela adesão, a obediência pelo reconhecimento (GAULEJAC, 2005 p. 109).

O autor ainda aponta outra característica do gerencialismo quando este promete um universo "sem limites: zero atraso, zero falha, zero de papel, qualidade total e etc." (GAULEJAC, 2005, p. 123).

Pagès et al. (1987 apud CALGARO; SIQUEIRA, 2008, p. 118) consideram "essas novas práticas gerenciais como totalitárias, controlando o indivíduo por meio da interiorização de suas exigências, agora muito mais abrangente, pois são de ordem política, econômica, ideológica e psicológica".

A implantação do modelo gerencial no Brasil, sob coordenação do Ministro da Administração e Reforma do Estado, Bresser Pereira, acompanhou os modismos gerenciais, principalmente a Qualidade Total, Benchmarking e reengenharia (CALGARO, 2007), seguindo exemplo do que aconteceu com os Estados e Unidos e com o Reino Unido, priorizou a reforma do Estado, baseado nos princípios gerencialista de transferência à iniciativa privada de atividades até então exercidas pelo próprio Estado. (CALGARO; SIQUEIRA 2008, p. 119).

Como justificativa, Bresser-Pereira (1998 apud CALGARO; SIQUEIRA, 2008, p. 119) afirmou que "o Estado burocrático weberiano não atendia os anseios, cada vez mais presentes, da sociedade brasileira" e que era "preciso urgentemente adotar reformas constitucionais que abrangessem as áreas fiscais, previdência social e eliminação de monopólios". 
Também foi proposta no Plano Diretor da Reforma do Estado a flexibilização da estabilidade dos servidores públicos. Para Mota e Bresser-Pereira (2004, apud MATOS; LIMA, 2007, p. 7), "a maioria das disfunções da burocracia é decorrente da imprevisibilidade do comportamento dos funcionários, que para combater a rigidez, o formalismo e a impessoalidade, desenvolvem a organização informal como forma de defesa".

Para Bresser-Pereira (1998 apud PAULA, 2005), a diferença entre a burocracia e a nova gestão pública reside no fato que esta segue os princípios do gerencialismo e tem como principais objetivos

melhorar as decisões estratégicas do governo e da burocracia, garantir a propriedade e o contrato, promovendo um bom funcionamento dos mercados, garantir a autonomia e a capacitação gerencial do administrador público e assegurar a democracia através da prestação de serviços públicos orientados para o 'cidadãocliente' e controlados pela sociedade (PAULA, 2005 p. 130).

Para Gaulejac (2007), é muito perigoso associar o cidadão a um cliente, haja vista que quando o cidadão é tratado como cliente, ele se torna exigente, mas o foco se resume à relação comercial, não dando conta o cidadão que ali é também responsabilidade sua. Por exemplo, “o pagamento de impostos não é mais um ato de cidadania, fundado sobre a honra de contribuir com o bem comum, mas uma corvéia que é preciso o quanto possível suprimir, utilizando as múltiplas oportunidades de desfiscalização, ou instalando-se em paraísos fiscais” (GAULEJAC, 2007, p. 279).

O cidadão-cliente passa a exigir do sistema político que se transforme em um balcão de reclamação, pronto a ouvir suas queixas como cliente, não mais como cidadão, parte integrante desse sistema.

De acordo com Paula (2005), o novo modelo de gestão proposto para alcançar seus objetivos deveria, além de ser seguido por todos os níveis administrativos, ter como características

uma administração profissional, autônoma e organização organizada em carreiras; descentralização administrativa; maior competição entre as unidades administrativas; disciplina e parcimônia no uso dos recursos; indicadores de desempenho transparentes; maior controle dos resultados; e ênfase no uso de práticas de gestão originadas no setor privado (PAULA, 2005 p. 130).

Para o presente estudo, a influência organizacional que o gerencialismo exerce sobre a gestão do serviço público, em especial a ênfase ao uso de ferramentas e práticas de gestão de pessoas originadas no setor privado no judiciário brasileiro que não é diferente dos outros poderes, vem sendo massacrada pela mídia e pela opinião pública por sua lentidão em julgar. Além disso, o Poder Judiciário vem sendo incentivado, ou melhor, obrigado a se 
modernizar à luz do gerencialismo, visando diminuir o tempo de espera pelos julgamentos dos litígios.

Não podendo ser diferente, os princípios administrativos oriundos da empresa privada invadem toda a sociedade (CHANLAT, 2002), com "novas técnicas de organização do trabalho, as grandes empresas pretendem crescer progressivamente e aumentar seu grau de influência nas diversas instancias sociais" (SIQUEIRA, 2006, p. 32). O Poder Judiciário não escapa dessa intenção da cultura do management em influenciar toda a sociedade.

Cabe relembrar que, por si sós, as atividades de julgamento seguem ritos extremamente rígidos, tendo em vista a natureza do trabalho. Caso não se observe qualquer determinação legal, corre-se o risco de ver todo o processo judicial invalidado. Logo, por característica, a burocracia parece apresentar as melhores condições para a segurança jurídica. Nesse aspecto, vale registrar argumentação de Azevedo e Loureiro quando afirmam que

a administração burocrática é o modelo mais compatível com uma ordem política republicana e democrática, na qual o primado do interesse público sobre o particular e a igualdade de todos os cidadãos constitui idéias centrais. Legalidade, impessoalidade, regras formais e universais são os princípios que normativamente devem orientar não só a ação dos funcionários quando executam as funções de recrutamento, promoção, avaliação e controle dos atos e omissões de membros do aparato estatal (AZEVEDO; LOUREIRO, 2.003, p. 44)

\section{2 - O Gerencialismo e seus Discursos}

Dentro do contexto da cultura do management, "as crenças gerenciais engendraram a constituição de ferramentas e práticas administrativas que supostamente conduzem a excelência empresarial". O "modismo gerencial" é condicionado para a pressão pela eficiência, excelência e sucesso. A administração da qualidade total e reengenharia servem de exemplo de modismos gerenciais.

Não podendo ser diferente, a Reforma do Aparelho do Estado, proposta por Bresser-Perreira, no Plano Diretor da Reforma do Estado, contempla essas ferramentas. Foram criados o Programa de Qualidade e Participação e o Programa de Reestruturação e Qualidade dos Ministérios, definidos como "um instrumento para a mudança de uma cultura burocrática para uma cultura gerencial, necessária à implantação de um novo modelo de gestão do Estado, que valorize a participação e a iniciativa do servidor público" (BRESSERPERREIRA, 1997 apud PAULA, 2005, p. 131). Os técnicos do Ministério da Administração e Reforma do Estado (Mare) também recomendam o uso de ferramentas gerencialistas, 
principalmente o PDCA e Benchmarking, que, para eles, significa a imitação e reprodução de processos, técnicas e práticas administrativas bem sucedidas (PAULA, 2005).

As ferramentas de gestão introduzidas pelo neoliberalismo em busca de eficiência e eficácia fazem parte do nosso dia-a-dia (PAULA, 2005 apud CALGARO, SIQUEIRA, 2008) e, além da qualidade total e da reengenharia, downsizing, empowerment, gestão de desempenho, modelos de excelência, balanced scorecard, dentre outros, são exemplos (CALGARO, SIQUEIRA, 2008).

A administração da qualidade total (TQM) está intimamente ligada ao modelo japonês de produção, que foi capaz de surpreender os ocidentais por produzir com flexibilidade, baixo custo e qualidade. O chamado Toyotismo possibilita uma produção flexível.

Ao ocidentalizar a TQM, os países eliminaram elementos da cultura japonesa como a "estabilidade e vitaliciedade dos funcionários em seus cargos e funções; a empresa interpretada como uma família e a inter-relação entre a vida no trabalho e a vida social" (PAULA, 2005 p. 59), haja vista irem de encontro às premissas gerencialistas voltadas para o dinamismo e a mudança.

Collins (2000 apud PAULA, 2005) diz que a TQM é uma administração ambígua e se vale do discurso da eficiência e melhoria contínua, quando, na verdade, reelabora o controle e disciplina dos trabalhadores para facilitar as mudanças desejadas pela cúpula. Nessa mesma linha, Wood Jr. e Urdam (1995, apud PAULA, 2005) apontam que as normas rígidas para obtenção da certificação do ISO 9000 se assemelham aos métodos racionais, ou seja, travestiram o controle e a disciplina dos trabalhadores com o nome de modernidade.

Antunes (1999 apud PAULA, 2005) acredita que a TQM intensificou o trabalho e as estratégias de participação e apenas facilitou a apropriação dos conhecimentos, e mantém uma tendência taylorista.

Gaulejac (2007, p. 82), afirma que o discurso da qualidade total é circular, demonstrando não ter fim a busca pela qualidade e aponta que o

ideal de qualidade e os meios de alcançá-la, declinados a partir de certo número de noções, formam uma equação 'mágica': Qualidade $=$ Excelência $=$ Sucesso $=$ Progresso $=$ Desempenho $=$ Comprometimento $=$ satisfação das Necessidades $=$ Responsabilização $=$ Reconhecimento $=$ Qualidade..

A respeito da excelência, Farias e Oliveira (2007, p. 195) dizem 
que a busca do desempenho ideal - a excelência e o sucesso - iniciou-se nas indústrias e chegou às organizações em geral de um modo hegemônico, encontrando não só pouquíssimas resistências, mas um entusiasmado apoio, baseado na concepção acriticamente aceita de que da qualidade só se discute as formas de obter, pois ela é em si mesma uma exigência universal.

Retornando a Gaulejac (2007, p. 81), este afirma que “a qualidade é uma utopia mobilizadora que suscita, em primeiro lugar, o entusiasmo e o consenso. Ela permite ultrapassar os objetivos de desempenho, de rentabilidade, de proveito, que conotam preocupações ‘baixamente’ financeiras”.

Não devemos esquecer que a qualidade total é semelhante ao culto da excelência, uma vez que ambos fazem parte do "imaginário ilusório, onde o objetivo é fazer indivíduos conformes que respeitem o ideal da organização" (ENRIQUEZ, 1997b, p. 13), ou seja, tentam incutir no indivíduo que existe erro zero e herói. O trabalhador busca cada vez mais a excelência; se não a consegue, se vê frustrado, incompetente, tornando-se neurótico.

Aubert (1993, p. 87) afirma que "a neurose de excelência mostra como certas situações organizacionais provocam em alguns tipos de personalidade que buscam um ideal profissional elevado e investem na instituição, o estabelecimento de processos neuróticos".

Por fim, Gaulejac (2007, p.105) afirma que a qualidade é uma figura do poder gerencialista e "a idéia da qualidade, principalmente quando lhe acrescentamos o termo 'total', refere-se a um mundo da pureza. Um mundo sem defeito, no qual cada um realizará sua tarefa perfeitamente”. Novamente vemos que a qualidade é uma utopia a serviço de maiores lucros.

A reengenharia parte do pressuposto de que todos os processos precisam ser refeitos, esquecidos, desprezados. Para isso, requer uma reestruturação radical dos processos empresarias por meio do downsizing, da terceirização das atividades que não criam valor agregado e o uso intensivo das tecnologias de informação (PAULA, 2005).

Segundo Siqueira (2006), em um contexto de desenvolvimento tecnológico, a reengenharia seria apenas um dos inúmeros modismos gerenciais recente, que proporcionaram ao indivíduo um cenário de angústia e ansiedade plenamente justificáveis, haja vista a quantidade de empregos que desapareceram em nome da reestruturação e de maiores lucros. Sem contar "que as reestruturações radicais afetam o equilíbrio das organizações" (PAULA, 2005, p. 92).

Michael Hammer, o pai da reengenharia, reconheceu seu erro com a frase "hoje percebo que estava errado", (REVISTA EXAME, apud VERGARA, 2003, p. 13). 
Empowerment é o comprometimento dos empregados com os objetivos de melhorar o desempenho organizacional. Para tanto, permitem a participação dos funcionários nas decisões estratégicas.

Paula (2005) discute que a emancipação participativa não leva a uma emancipação do trabalhador, mas implica sim que os trabalhadores terão mais encargos sem as devidas e proporcionais compensações. Antes, reduz custos para as empresas. Além disso, atualmente o mundo do trabalho é regido pela instabilidade, pressão pela eficiência e competição, o trabalho em grupo é dificultado e o comprometimento é de curto prazo.

Benchmarking é o processo pelo qual uma empresa busca com a concorrência, fornecedores e parceiros as melhores práticas de gestão e produção visando à maximização do desempenho empresarial.

Renault (2005, p. 130) parte da "premissa de que a reforma do Judiciário passa pela modernização da sua gestão" e que, dentre outras ações, está o "apoio a projetos de financiamento para a modernização e a desburocratização da máquina administrativa". Completa a afirmação quando diz que a "melhor metodologia a ser desenvolvida é a captação das melhores experiências de gestão (best practices)".

Marini (2002, p. 33) nos diz que "umas das principais tendências da gestão contemporânea, na perspectiva do desenvolvimento organizacional, tem sido o intercâmbio de experiências institucionais a partir da disseminação das melhores práticas". O que ele chama de análise comparativa confronta seus modelos de gestão à luz daquelas práticas tidas como mais avançadas.

O Benchmarking é prática que se iniciou na iniciativa privada, atualmente utilizada em larga escala pelas empresas do setor público, inclusive "tem sido recomendada pelos organismos internacionais" (MARINI, 2002, p. 33).

A gestão por competência, no entender de Faria e Leal (2007, p. 147), é “um movimento que mobiliza intelectuais orgânicos tanto das instituições de ensino como no interior das próprias organizações, e incorpora um conjunto de ordem política e ideológica, historicamente relacionados com os interesses do capital”.

Para esses autores, Faria e Leal (2007), a gestão por competências é uma forma de trazer mais vantagens competitivas para as empresas. Da origem da própria palavra competência, “competir, concorrer, buscar a mesma coisa que outro, atacar, hostilizar" Houaiss (2001, apud FARIA E LEAL, 2007, p. 145), percebe-se que dotar uma pessoa de competências seria o mesmo que prepará-la para a guerra do mercado. 
Outro fator interessante é que atualmente, quando se pensa em competir, as empresas deslocam a competição para o âmbito pessoal, uma vez que elas alimentam a concorrência entre trabalhadores, deslocando "as contradições do plano capital-trabalho para o plano intertrabalhadores” (FARIA e LEAL, 2007, p. 148), daí provém que agora as empresas são parceiras e os colegas sentados ao lado, inimigos. Devemos, neste contexto, ser individualista.

Atualmente, as empresas, sejam públicas ou privadas, buscam a gestão por competência justamente para se prepararem e enfrentarem o mercado que cada dia mais exige flexibilidade no contexto de competição. Logo, a demanda por capacitação do desenvolvimento não pode ser assim, solta, deve sim seguir parâmetros de auto-regulagem dos indivíduos que buscam adequar seus interesses aos do mercado. A empresa tenta incutir nos trabalhadores que os objetivos dos dois, empregado e empresa, são os mesmos.

Geralmente, as capacidades ou competências requeridas são de cunho bastante abstrato. Ao contrário de descrever cargos, descreve a equação Conhecimentos, Habilidades e Atitudes (CHA). Para cada competência, serão descritos os CHA’s específicos.

No contexto da gestão por competências, temos ainda que a gestão da carreira agora deve passar a ser responsabilidade do trabalhador. A organização, após descrever as competências que julga se adequarem à estratégia da empresa, demonstra que, se o indivíduo quiser entrar ou permanecer nela, terá de se autodesenvolver nos moldes ou dentro das competências estabelecidas. A empresa fornece alguns cursos e treinamentos básicos, o aprofundamento é por conta do empregado.

Para autogerenciar sua carreira ou se autodesenvolver, a pessoa passa a fazer vários cursos, MBA, especializações, etc., tudo fora do horário de trabalho, de forma não concorrente ao trabalho. Os custos também são seus. Ao pensar no modelo taylorista, essa responsabilidade e custos eram arcados pela empresa.

Por fim, a gestão de competência funciona como uma forma de ditar um padrão de comportamento que hierarquiza os trabalhadores, recompensando os competentes e talentosos, e punindo os incompetentes, além de estabelecer os níveis de competências mínimas que os manterão empregados ou não, ou seja, manipula a sua psique para os objetivos da empresa e conformes a esta.

Idealmente, a busca por ferramentas, práticas ou modismos gerenciais deveria se pautar pelo que produzisse, ao mesmo tempo, melhores resultados para a empresa e melhores condições de trabalho para os empregados. Mas não, normalmente deseja apenas diminuir custos em detrimento das condições de trabalho. E, em relação às práticas 
importadas, algumas são aplicadas apenas para dar ar de modernidade à empresa, haja vista não serem úteis nem interessantes para a organização.

Faria (2007, p. xvii) condena tais práticas argumentando que essas "recomendações são superficiais e que um conjunto de procedimentos que opera como mandamentos quando funcionam duram pouco tempo". Não é de se estranhar o pouco tempo de durabilidade das receitas organizacionais, ou best practices, na vida de uma empresa, justamente por ser a organização dinâmica e complexa. E quando se coloca em prática qualquer procedimento, o ambiente muda e as recomendações adotadas no início já não servem para a seqüência, conclui ele.

Pagès (1993) afirma que, apesar de a nossa sociedade ser de informação, onde os indivíduos, de uma forma geral, são mais esclarecidos e estão mais aptos a entender a complexidade contemporânea,

\footnotetext{
os trabalhadores das empresas hipermodernas, especialmente os executivos e os empregados são, ao mesmo tempo, mais alienados que seus antecessores, mais enquadrados, mais integrados, pois eles são pegos como mostramos, num sistema que os encerra de todos os lados e os toma totalmente de corpo e alma (Pagès et al, 1993, p. 233).
}

Isso não deixa de ser um imenso paradoxo e requer uma profunda reflexão. Temos mais informações e menos consciência crítica para analisarmos. Como seremos prudentes ao efetuar o Benchmarking em um ambiente assim?

Os servidores públicos, principalmente os gestores que trabalham na organização pública pesquisada, são considerados bem informados, tendo em seu quadro especialistas, mestres e doutores. A presente pesquisa tentará identificar se os gestores de pessoas têm percebido as conseqüências das práticas importadas sobre as condições de trabalho.

De qualquer forma, os discursos que prometem solucionar todos os problemas das organizações por meio dos modismos gerenciais são objetos de crítica de vários autores, justamente porque seria notável encontrar livros de receitas que resolvessem todos os problemas organizacionais.

Nas considerações iniciais do livro Análise Crítica das Teorias e Práticas Organizacionais, Faria (2007, p. xvii) dá enfoque ao fato de "que as prateleiras de pop management estão repletas de livros de receitas que prometem soluções maravilhosas para os gestores em 10 lições práticas". Continua o autor afirmando que o gestor descobre como esconder o queijo e aplicar com sucesso os segredos da arte de administrar utilizada pelos antigos astecas e maias, exemplos de liderança de personagens bíblicos e que o primeiro 
psicólogo do mundo tinha 12 pacientes. Esses autores, que estão fazendo fortuna com receitas para todos os gostos, só vendem por existirem consumidores ávidos por soluções prontas e de fácil aplicação, pois os leitores não querem ou não têm tempo de refletir de forma crítica. Vergara (2003, p. 13) questiona se já

reparamos quantos renomados consultores internacionais pregam, eloqüentemente, determinadas estratégias para logo depois se desdizerem? Michael Hammer, pai da reengenharia, com o seu "hoje percebo que estava errado". Roberto Tomasko e também sua mea culpa acerca do downsizing e Tom Peters com seu "esqueçam o que escrevi", são bons exemplos.

Será que, de fato, as práticas administrativas do setor privado são eficientes? Paula (2005, p. 92) acredita que não é bem assim e cita os "escândalos empresariais recentes, como o caso Enron. A empresa estadunidense do setor de energia que havia sido aclamada por seu modelo eficiente e bem sucedido de administração". A empresa não só faliu, como mostrou que seu sucesso fazia parte de uma rede de corrupção para lhe dar credibilidade.

Freitas (2006, p. 2), em resenha do livro de Judith Mair, Chega de Oba-Oba, 2.005, afirma que essa empresária do ramo da publicidade se mostra "cética em relação aos modismos gerenciais, as sugestões embusteiras de empresas de consultoria que tentam fazer crer que trabalho e lazer são as mesmas coisas". Segundo a autora, esse livro pode ser visto como "uma bela, irreverente e pertinente contribuição às áreas de recursos humanos e análise organizacional", particularmente no que diz respeito ao falso endeusamento de culturas empresariais e a natureza de controle motivacional escondido sob o manto da sedução.

Não resta dúvida de que existe um grande incentivo para que os órgãos públicos adotem várias ferramentas da gestão privada, ora pela desvalorização do servidor, ora pela crise do Estado, ora pelas notícias veiculadas na imprensa, mas o que nos chama a atenção é que se essas práticas forem postas no serviço público tal qual na iniciativa privada, o que acontecerá com as políticas públicas? Terão o mesmo que fim que as estratégias das empresas privadas, que tendem a enfatizar objetivos de curto prazo? (PAULA, 2005).

As políticas públicas, salvo em caso de calamidade, têm ou deveriam ter como característica as ações de longo prazo. São perenes e delas se espera retorno no tempo; as estratégias privadas também, mas os exemplos mostram que a preocupação destas é com os lucros aqui e agora. 


\section{3 - Discurso Organizacional em Gestão de Pessoas}

Curado, Pereira Filho e Wood Jr (1995) realizaram uma pesquisa na grande São Paulo com o objetivo de conhecer melhor a gestão de recursos humanos, Mitos e Realidades da Gestão de Recursos Humanos, e foram surpreendidos por um cenário pouco avançado da gestão de recursos humanos, justamente por se falar tanto, na época atual, sobre sua importância para as organizações. Eles afirmam que, devido à abertura da economia e a introdução de novas práticas gerenciais, as organizações nacionais vêm investindo em um processo de modernização.

Para os pesquisadores (CURADO, PEREIRA FILHO e WOOD JR., 1995) a mídia especializada em assuntos organizacionais divulga várias experiências de sucesso, narrando casos de empresas inovadoras no Brasil e no exterior. Com exceção no ambiente de pesquisa acadêmica, encontrar qualquer publicação de casos de insucesso se torna muito difícil e, quando se acha, logo encontra um culpado: os indivíduos retrógrados e ultrapassados que resistem à modernidade.

Para Siqueira (2006, p. 24), "os recursos humanos se tornaram umas das grandes preocupações das organizações nas últimas décadas, especialmente preocupações em processos de mudança organizacional". Parece lógico investir nesse setor, mas será que essa preocupação ultrapassa o discurso?

Na percepção dos profissionais de recursos humanos, o nível de planejamento e investimento que as empresas aplicam no departamento de gestão de pessoas tem aspecto negativo e são vistas as "suas áreas como insuficientemente valorizadas e pouco estruturadas" (CURADO; PEREIRA FILHO; WOOD JR., 1995, p. 7).

Outra constatação dessa pesquisa foram os programas planejados de mudança organizacionais que têm a participação institucional do RH. Esses programas estão basicamente ligados à gestão da qualidade e da reengenharia, que, aliados ao benchmarking, são os modismos gerenciais incentivados pela reforma gerencial da administração pública, proposta por Bresser-Pereira, seguindo exemplo do que aconteceu com os Estados Unidos e Reino Unido (CALGARO, SIQUEIRA 2008, p. 119).

Nesse enfoque, Beaujolin (1998, apud DAVEL; VERGARA, 2008, p. 40) afirma que, no discurso, os gestores evocam "pessoas como estratégicas, de fato e nos fatos constata-se que elas são enquadradas em um movimento permanente de racionalização de custos como, por exemplo, redução de pessoal", ou seja, no discurso, a gestão de pessoas é 
essencial e estratégica, mas, na prática, o essencial mesmo é ela servir de apoio à redução de custos.

Reforçando essa idéia, Lima (1994, apud DAVEL; VERGARA, 2008, p. 40) diz que a "gestão de pessoas pode, então, estar veiculando um discurso de facilitar ou de acompanhar a integração dos empregados, a democratização e a humanização das empresas, mas, na prática, opera pelo desenvolvimento dos processos de exclusão e de auto-exclusão".

Não podemos falar em discursos organizacionais sem antes defini-lo. Usaremos a definição de Faria e Meneghetti, (2.001, p. 128), para quem discursos organizacionais são "genericamente, formas manifestas de expressão de idéias, valores e sentimentos, sejam estas formas ou ocultas, explícitas ou implícitas".

O poder que os departamentos de recursos humanos manifestam dentro das organizações modernas é enorme e "diferencia-se de outros campos conexos por explicar e facilitar a influência da gestão sobre os comportamentos das pessoas, a fim de resultar em um funcionamento eficaz e eficiente da organização" (BRABET, 1993 apud DAVEL; VERGARA, 2007, p 34).

Por outro lado, o departamento de recursos humanos utiliza as políticas de pessoal que

não funcionam apenas como mediação econômica, elas tem também uma função ideológica, reforçando a ideologia oficial de respeito ao indivíduo, de igualdade de oportunidade etc., e são reforçadas por ela no que se traduz no discurso pela insistência no fato de que os grandes princípios são aplicados (PAGÈS et al, 1993, p. 27).

Siqueira (2006) pergunta o que leva uma pessoa, um empregado a querer ser escravo em uma empresa e obedecer a gerentes, normas e regras? Com certeza os meios para se conseguir que o indivíduo os sirva estão presentes no discurso organizacional em gestão de pessoas que, através de suas políticas, influenciam o comportamento dos indivíduos, que, além de agir como mediadores econômicos, disseminam a ideologia oficial da organização e insistem em seus grandes princípios.

Os departamentos de recursos humanos, modernamente chamados gestão de pessoas, seria uma forma de o capitalismo buscar o desenvolvimento e perpetuação e aumentar seus

mecanismos do poder, indo até a manipulação do inconsciente. E é aí que reside um problema fundamental na interpretação dos mecanismos de dominação. A dominação é o produto de uma mescla de coerção e de aceitação, este último elemento talvez seja o mais forte (PAGES et AL, 1993, p. 227). 
Antes de tentar entender como se manifesta o poder das organizações, ou melhor, como a organização consegue esse poder, uma vez que elas "não são entes abstratos, sujeitos absolutos, entidades plenamente autônomas, unidades totalizadoras e independentes, mas construções sociais dinâmicas e contraditórias, nas quais convivem estruturas formais e subjetivas, manifestas e ocultas, concretas e imaginárias" (FARIA 2007, p. 3), temos que vencer primeiro um dos grandes desafios das ciências sociais de hoje: libertar-se, haja vista que "cada vez mais se submete à lógica do capital, torna-se força produtiva deste, ou seja, o conhecimento passa a ser balizado pelos interesses do capital" (HABERMAS, 1982, apud FARIA, 2007, p. 9), faremos uso da teoria crítica, vista como radical, o que é verdade, mas não no sentido pejorativo, e sim no sentido de tentar entender os problemas organizacionais a fundo. Não se contentando, quem dela faz uso compreender "a forma sem o conteúdo e nem a aparência sem essência" (FARIA, 2007, p. 10).

Para Siqueira (2.006 p. 70), existem várias fontes de poder, dentre elas podemos destacar o conhecimento, o amor-fusão, a identificação, que abordaremos a seguir, além do poder da autoridade formal, do controle sobre recursos escassos, do processo decisório, da organização informal e a informação, da habilidade em se lidar com a incerteza, do uso da estrutura organizacional, das regras e os regulamentos, da possessão dos meios de sanção, da competência do líder e da legitimidade, uma vez que “o poder pretende ser legítimo (...) e é na legitimidade que o poder consegue a conquista da adesão e a mantém por um bom tempo” (SIQUEIRA, p. 68).

O poder que o tecnocrata detém, para Mota e Enriquez (1996; 1991 apud SIQUEIRA, 2006, p. 69), advém da competência técnica, ou seja, do conhecimento que “é uma das principais e mais claras fontes de poder nas organizações. Trata-se do poder legal”, justamente por ser este indivíduo quem vai definir e planejar como as tarefas e atividades serão executadas.

Este poder tem relação direta com a burocracia, embora os gerentes ou os defensores do gerencialismo dele não abram mão, justamente por esse poder se basear nas relações impessoais, pois pertence ao cargo e não à pessoa. O que legitima o poder é o cargo; logo, o que fizer de bom é competência pessoal, o que for obrigado a fazer, como, por exemplo, demitir, é inerente ao cargo.

Retornando a Pagès et al (1993), quando estes afirmam que a dominação é o produto de uma mescla de coerção e de aceitação, sendo a aceitação o item mais forte, os estudiosos que utilizam a teoria crítica sempre questionam o porquê de os empregados aceitarem a dominação. 
Para conseguir essa resposta é necessário que se conheça as políticas de pessoas, que sempre se renovam, haja vista que

as tecnologias de controle psicossocial e político usa os estratagemas da linguagem, os programas de aprisionamento e sedução, enfim, tudo o que transmite duplas mensagens: oprime, ameaça, exige, cobra e age com violência, ao mesmo tempo em que elogia, agrada, age com simpatia e preocupação (FARIA, 2007, p. 13).

Nesse aspecto é que o poder do amor-fusão encontra guarida, pois o indivíduo ama de tal forma a organização que "passa a ter medo de perder suas próprias referências de identificação quando esta lhe faltar, tamanha é a entrega do indivíduo a ela, o qual se torna a principal referência em sua vida, o sentido principal de sua existência” (SIQUEIRA, 2006, p. 68).

Quando chega nesse ponto, além de o indivíduo procurar a servidão de maneira voluntária, ele se submete ao sacrifício e "trabalhar sem cessar para o bem de todos, em detrimento de sua saúde e de sua vida familiar” (LE GOFF apud SIQUEIRA, 2006, p. 69) vira uma constante até ser desligado da empresa, a qual se exime de qualquer responsabilidade pela dispensa, haja vista a culpa ser do mercado e, caso não o demita, a empresa corre o risco de fechar (SIQUEIRA, 2006).

Por sua vez, as empresas não querem apenas que façam o que ordenam, querem que se arrebentem, se atormentem, se matem, dedicando-se de corpo e mente para o sucesso de seus negócios (LE BOÈTIE apud SIQUEIRA, 2006), haja vista que o modelo gerencialista evoca sua dimensão narcísica. A empresa "propõe ao homem gerencial satisfazer seus fantasmas de onipotência e seus desejos de sucesso, contra uma adesão total e uma mobilização psíquica intensa” (GAULEJAC, 2007, p. 117).

Através da fascinação e da sedução, as empresas controlam e conseguem impor, de maneira suave, a sua cultura e dominar o inconsciente do indivíduo. Para Enriquez (1991 apud SIQUEIRA, 2006, p. 75) as características da relação da fascinação são a "submissão do indivíduo, o deixar de lado tudo aquilo que não diz respeito ao objeto amado, a ausência de crítica, a alienação e a submissão voluntária” e ela é obtida por meios de

ritos de grandes comemorações, de grandes festas triunfais...Os hipnotizadores lançam mãos do discurso de que cada pessoa que os siga pode se tornar um herói, um ser imortal, torna-se uma pessoa acima das outras, objeto de reconhecimento e de admiração (ENRIQUEZ, 1991 apud SIQUEIRA, 2006, p. 75).

Nesse momento, as pessoas já estão possuídas, ou melhor, hipnotizadas intrinsecamente por seu próprio narcisismo que substitui os desejos pessoais tais como uma família estável e feliz ter mais tempo com os filhos e esposa, e passam a buscar o 
reconhecimento, a admiração e ser referência para as outras pessoas. Tudo isso apenas no campo profissional.

Para Freitas (2000, p. 11), nesse momento, a empresa propõe ao indivíduo a "fantasia do ser um, traduzida no eu faço parte da organização e ela faz parte de mim, o sucesso dela é o meu sucesso e vice-versa”, ou seja, os objetivos da empresa são meus e ela preencherá meus desejos narcísicos.

Fugindo do sagrado proporcionado pela fascinação, “a sedução reside na aparência: um sorriso insinuante, palavras escolhidas com precaução, frases agradavelmente balanceadas, certa banalização dos problemas permitem ao discurso ser suficientemente agradável” (ENRIQUEZ, 1991 apud SIQUEIRA, 2006, P. 76).

Freitas (2000 apud SIQUEIRA, 2006, p. 76) entende a sedução como um convite "a uma fantasia de rara beleza, como um processo, uma relação dual, fugitiva em sua promessa de charme e intensidade das emoções prazerosas que podem ocorrer nesse encontro sugerido com a magia e o encantamento a ser desfrutado".

Também na sedução, a empresa utiliza o próprio sentimento narcísico do indivíduo e vai trabalhando com ele na viabilização de um projeto que venha a alcançar o ideal que a empresa quer para si mesma, em que o empregado é convidado a participar e "se sente feliz e gratificado pela honra concedida a ele” (SIQUEIRA, 2006, p, 78).

Para Siqueira (2006), tanto a fascinação quanto a sedução necessitam da atuação de um líder que precisa ter as características de inspirar os empregados a levar os projetos da empresa à frente como se fossem seus, comprometendo-se e substituindo o seu imaginário pelo imaginário da organização. O papel do líder ainda é o de servir de referência de como agir e de como se comportar na vida profissional e na vida pessoal. "Os cegos de amor vêem dos líderes que mostram o caminho a ser seguido” (SIQUEIRA, 2006, p. 79).

Pagès (1993, p. 73) afirma que o indivíduo “se imagina construindo o mundo, enquanto na realidade ele está sendo produzido, investido por todas as partes e modelado até no seu interior”.

De acordo com Enriquez (1991 apud SIQUEIRA, 2006, p. 77), a sedução se torna um mecanismo eficaz de comprometimento do trabalho e os "dirigentes sabem que para tornar a organização dinâmica (e não eliminada pelo mercado) é necessário tornar mais fácil a identificação de seus membros ao projeto que ele propõe a fim de que eles consagrem sua força e seu talento a seu sucesso".

Essa identificação pode ser notada no toyotismo - team work, kaizen, just in time, controle da qualidade - já que esse foi capaz de propiciar o seqüestro da subjetividade 
do trabalhador e, assim, levá-lo a aceitar condições físicas e psicológicas de trabalhos cada vez mais precárias (FARIA; MENEGUETTI, 2007, p. 56), tomando o espaço da racionalização taylorista-fordista que não atingia o nível de seqüestrar a subjetividade do indivíduo.

Em uma pesquisa, Faria e Meneghetti (2007) analisaram a percepção dos trabalhadores decasséguis de uma fábrica que adota o chamado modelo toyotista de produção e gestão e identificaram cinco formas de seqüestro de subjetividade.

Pela Identificação: introjeta no trabalhador, como se fora parte de si, o imaginário instituído pela organização.

Pela Essencialidade Valorizada: faz o trabalhador se julgar indispensável por motivo de merecimento, crença no reconhecimento dos seus méritos por parte da organização.

Pela Colaboração Solidária: a concepção de grupo acima de tudo. Desenvolvimento de atitudes voltadas para a contribuição do trabalhador para os projetos organizacionais.

Pela Eficácia Produtiva: faz o trabalhador crer e colaborar efetivamente com a obtenção de melhores resultados do que aqueles previamente previstos.

Pelo Envolvimento Total: o trabalhador se entrega à sedução e ao encantamento proporcionado por valores oferecidos pela organização.

Utilizando-se de um tipo hábil de violência psicológica e da manipulação do comportamento com o intuito de submeter o indivíduo à sua ideologia, a organização seqüestra sua subjetividade (FARIA e MENEGHETTI, 2007). Ao fazer uso dessas formas aliado a desterritorialização, seqüestrá-la se torna ainda mais factível, vez que o "território é, antes de tudo, o espaço no qual se enraíza nossa identidade, o lugar de nossos prazeres, de nossos temores, de nossas relações importantes, a superfície de inscrição e nossa história pessoal, enfim o conjunto de nosso sistema de referência" (PAGÈS et al, 1 993, p. 119).

Sem o indivíduo pertencer mais "a um lugar específico, ele não está mais preso a raízes familiares, muito menos de vizinhança" (FREITAS, 2000, p. 8), a organização passa a ser assim sua referência e produzirá seus efeitos na história do indivíduo, que "não transcorre mais no ritmo de nascimentos, aniversários e falecimentos, mas, muito mais no ritmo da carreira: admissão, as promoções, os estágios, os aumentos são os acontecimentos que marcam data" (PAGÈS et al, 1 993, p. 119).

Assim como Siqueira (2006, p. 15) optou por analisar as organizações “a partir de uma dimensão crítica", concordamos com ele quando afirma que compreender o "discurso organizacional em gestão de pessoas, ou melhor, as suas várias categorias, são conhecer um 
pouco mais sobre as organizações". Do mesmo modo, "sabemos que é possível desenvolver um conjunto de estudos sobre a vida organizacional sem cair na velha tentação de produzir uma receita de como ganhar mais dinheiro ou arrancar mais produtividade". (FREITAS, 2000, p. 42, apud SIQUEIRA, 2006, 103).

Dentre os discursos em gestão de pessoas existentes nas organizações, Siqueira (2006) os dividiu em seis categorias.

O discurso do superexecutivo de sucesso mostra que atualmente as empresas querem, antes de qualquer coisa, pessoas que se dediquem integralmente, pessoas obstinadas pelo sucesso.

"A carreira e o status profissional tornam-se os elementos organizadores da vida do indivíduo, aquilo que lhe dá sentido, auto-imagem e reconhecimento, único referente capaz de proporcionar-lhe sucesso e realização pessoal" (FREITAS, 2000, p. 63, apud SIQUEIRA 2006, p. 113). Nesse momento, o principal é vencer para ser reconhecido e admirado. As organizações modernas conseguem incutir nas pessoas a vontade de vencer através, principalmente, da necessidade destas em serem reconhecidas na valorização que estas dão ao sucesso, no deslocamento dos objetivos econômicos para o plano psicológico e pela alienação do desejo (PAGÈS et al, 1993).

Os empregados, em nome das carreiras, passam a administrar a "contradição entre uma carga de trabalho opressiva, uma tensão permanente, pressões importantes; de outro, de seus desejos de liberdade e autonomia (...), pois o desejo de vencer o leva a trabalhar sempre mais e melhor" (PAGÈS et al, 1993, p. 133). Estes ainda estão tão encerrados nas estruturas estratégicas de grandes empresas que aceitam ser valorizados e exigidos como "indivíduos ganhadores, esportistas, verdadeiros guerreiros que estejam dispostos a tudo pela vitória" (ENRIQUEZ, 2000 apud SIQUEIRA, 2006, p. 115).

Na época da aposentadoria ou até mesmo de uma provável e não rara demissão, esse "superexecutivo de sucesso, admirado, sempre no centro das decisões, o indivíduo poderá também vivenciar o sofrimento ocasionado pela perda da posição" (SIQUEIRA, 2006, p. 130), causando um sofrimento, ora pela perda do status, ora por não estar no centro das decisões. Segundo Enriquez (1991, apud SIQUEIRA, 2006, p. 131), "o poder é totalitário e seu possuidor se nega de todas as formas a abrir mão dele, pretendendo sempre à manutenção e a estabilidade".

Depois de perseguir o poder, de aceitar ser um escravo pela ambição, de fazer um pacto com o diabo e renunciar a si mesmo, "a ilusão do poder não se paga somente com uma carga de trabalho considerável, produz, sobretudo a dependência e a submissão do 
indivíduo que deixa de se pertencer" (PAGÈS et al, 1993, p. 14l), agora que ele é de corpo, alma e psique da organização, ela não lhe quer mais. No fim, os superexecutivos são "esquecidos, menosprezados, considerados como obsoletos, estagnados, sofrem descaso das empresas quanto a seus currículos" (SIQUEIRA, 2006, p. 134).

O Discurso do Comprometimento Organizacional seria o vestir a camisa da empresa, o comprometimento do indivíduo com os objetivos da empresa e a internalização da cultura organizacional - ou o trabalhador se compromete ou está fora. Os discursos da sedução, fascinação e da servidão voluntária são percebidos claramente neste tópico. (SIQUEIRA, 2006, p. 104).

De acordo com Bastos (1994, p. 28, apud SIQUEIRA, 2006, p. 137), "o comprometimento está relacionado ao desejo de permanecer como membro da organização, ao orgulho de pertencer a ela, à identificação com objetivos e valores da organização e ao próprio empenho que indivíduo faz em prol da empresa".

Segundo Faria e Barbosa (2007), o comprometimento do indivíduo para com a organização se forma através de três vínculos diferentes: base de comprometimento afetiva, instrumental e normativa.

Ordem afetiva é o vínculo que se estabelece pela existência de afeição, apego, identificação, reconhecimento e lealdade entre o indivíduo e a organização.

Ordem instrumental é o vínculo que se estabelece pela ótica dos custos e benefícios relacionados à ação.

Ordem normativa é o vínculo que se dá pela identificação e aceitação subjetiva das normas, valores e padrões estabelecidos como seus, concordando moralmente com os valores e objetivos da organização.

Vivemos períodos de demissão em massa e as empresas que se viram obrigadas, ou melhor, optaram por diminuir pessoal e melhorar seus resultados, hoje se vêem obrigadas a manter os empregados mais bem sucedidos, concedendo-lhes inúmeros benefícios e vantagens. Precisam também tirar a má impressão das demissões. As empresas necessitam de empregados comprometidos e educados sob a percepção corporativa que, aliada à gestão de competência, confere ao ativo humano o papel de suprema importância na realização dos objetivos organizacionais (SIQUEIRA, 2006).

Enquanto as empresas, como dito acima, procuram manter seus melhores quadros, os empregados que resistiram à reengenharia são incentivados a mudar a postura, como afirma Freitas (1999, p. 6 apud SIQUEIRA 2006, p. 136), "o profissional sério, consciencioso, leal e de longo prazo foi trocado ou estimulado a ser o jogador estrategista, o 
cara que contabiliza os ganhos do dia a dia e tem compromisso em primeiro, segundo e terceiro lugar apenas consigo e com seu caminho de sucesso".

Pagès et al (1993) trazem o conceito de individuação que, para os autores, é a única forma de a organização legitimar suas ideologias. No entanto, o indivíduo necessita estar isolado em relação ao sistema. "O sucesso individual é valorizado em detrimento da solidariedade. Ao considerar expressas individualmente no dispositivo, a organização evita e desintegra as reivindicações coletivas" (PAGÈS et al, 1993, p. 105).

As organizações utilizam-se de vários artifícios para comprometer os indivíduos com estas. Criam-se novos e melhores programas de comprometimento organizacional. Reuniões periódicas e informais entre os subordinados e os chefes visando apenas motivar os empregados a se envolverem e pensarem que estão ajudando a decidir, passando por narrativas de sucesso pessoal de grandes executivos: ele conseguiu, todos conseguem.

Esse discurso não se sustenta em hipótese alguma, vez que existem mais empregados que querem o cargo e status de executivo do que cadeiras à disposição. Outro artifício é o da afiliação. As empresas estão a cada dia mais presentes na vida dos empregados, ocupando o lugar que era de outras organizações, passando a ser o lugar das realizações, de brilhar e de tocar seus projetos pessoais adiante (SIQUEIRA, 2006).

Ainda de acordo com Siqueira (2006, p. 145), outro artifício utilizado pelas empresas é a doutrinação, que nada mais é que a "socialização dos indivíduos que estão entrando na empresa, especialmente trainees".

A doutrinação exercida pela empresa sobre os trainees se torna mais efetiva na busca de introjetar nestes todos os valores e ideologias, haja vista que ela, juntamente com os treinamentos, é um dos "principais mecanismos para conquistar o coração do funcionário" (SIQUEIRA, 2006, p. 147).

O investimento que objetiva a formação de "trabalhadores docilizados, não questionadores da realidade por eles vivenciada, produtivos e de baixo custo" (SEGNINI, 1996, p. 97, apud SIQUEIRA, 2006, P. 148) encontra guarida na instituição de escolas que servem no processo de assimilação de valores das classes dominantes. Logo, a doutrinação serve aqui não só às empresas, mas também à assimilação desses valores.

Para finalizar este tópico de comprometimento, citaremos um trecho de Leal (2003, p. 164, apud SIQUEIRA, 2006) que fala sobre a universidade corporativa, como instrumento de doutrinação que 
emerge num contexto organizacional atual como instrumento de controle social a serviço da gestão pela capacitação... além de explorar estratégias de controle de pensamento por meio da inculcação de uma ideologia da empresa percebe-se um esforço de controle da psique que apóia a gestão do afetivo (2003, p. 164, apud SIQUEIRA, 2006, p. 149).

O discurso da busca dos modismos gerenciais se reproduz nos ambientes organizacionais com a intenção de inserir os indivíduos na nova gestão proposta. Qualquer novidade, até mesmo um treinamento na selva que leve a empresa a aumentar seus lucros, é bem aceita.

Segundo Wood (1999, p. 87 apud SIQUEIRA, 2006, 151), as empresas "não adotam novas técnicas de administração por causa de uma avaliação racional da situação e dos benefícios, mas porque seus concorrentes estão adotando alternativas similares". As empresas assim são vistas como empresas modernas e adaptadas aos novos tempos.

Como fomentadoras desse processo estão as consultorias especializadas em reestruturação organizacional, buscando a modernização e a desburocratização dos processos de trabalho (SIQUEIRA, 2006, p. 154). Como já tratado no Capítulo 2.2 - Gerencialismo e Seus Discursos, os modismos gerenciais são bastante incentivados pela reforma gerencial.

O discurso do "ganhe com a participação" trata da participação do empregado tanto nos processos decisórios quanto nos lucros da empresa.

Com relação ao tópico financeiro, as empresas modernas não perderam as "raízes do pensamento taylorista que de fato nunca deixaram de estar presente na gestão das organizações, sobretudo no que diz respeito a esta visão de que o fator que mais motiva o empregado é a remuneração" (SIQUEIRA, 2006, p. 165). O autor continua afirmando que a participação financeira se concretiza por meio de gratificações de produtividade, onde "cenouras são colocadas na frente do coelho, e cada vez que o coelho consegue chegar à cenoura, aumenta-se a distancia entre eles" (SIQUEIRA, 2006, p. 165). Cada vez mais os trabalhadores correm atrás de suas cenouras.

Facilmente, os trabalhadores são manipulados a aumentar produção e rentabilidade, proporcionando maiores ganhos aos donos do capital.

De outro modo, a empresa permite que os empregados tomem parte nas decisões, por meio do discurso da parceria, utilizando-se das técnicas da comunicação e participação. Uma conseqüência da administração participativa é a quebra de paradigmas e um novo modo de trabalhar, retirando, assim, parte do poder dos sindicatos, abrandando as insatisfações dos empregados e melhorando o clima organizacional (SIQUEIRA, 2006). 
Afinal de contas, a decisão foi nossa, não só da empresa. Aqui todos trabalham e decidem juntos.

O discurso da saúde nas empresas mostra esta se preocupando com a saúde física e psíquica do trabalhador; ao mesmo tempo, contabilizam os custos com afastamentos, embora ignorem as possíveis causas das doenças, especialmente aquelas relacionadas ao ambiente de trabalho.

Como já mencionado, o indivíduo é pressionado a ter sucesso que

além do trabalho excessivo se desestruturam psicologicamente, tendo como conseqüência muitas vezes, graves problemas de saúde. O estresse, a ansiedade, a droga, o álcool são apenas alguns dos problemas gerados pela relação que o indivíduo mantém com o mundo do trabalho (SIQUEIRA, 2006, p. 169).

As organizações estão certas ao buscarem a reabilitação e a prevenção das doenças, mas "por outro lado, é necessário verificar qual a participação da empresa como causadora ou preconizadora das doenças de seus empregados", haja vista que vemos "indivíduos se violentarem ao realizar um trabalho não ético ou que possa prejudicar o bem estar social, em virtude das ambições da empresa" (SIQUEIRA, 2006, p. 170).

Neste tópico, discurso da saúde na empresa, um dos causadores de sofrimento e doença é o assedio moral, mais percebido nos dias atuais e definido como

toda e qualquer conduta abusiva manifestando-se, sobretudo, por comportamentos, palavras, atos, gestos, escritos que possam trazer a personalidade, a dignidade ou a integridade física ou psíquica de uma pessoa, pôr em perigo seu emprego ou degradar o ambiente de trabalho (HIRIGOYEN, 2002, p. 65 in SIQUEIRA, 2006, p. 65).

Como pode a empresa discursar pela saúde, se permite ou faz vista grossa do assédio moral em suas dependências?

Outro problema grave se refere ao uso de drogas lícitas ou ilícitas, que não chega a ser um problema para a empresa, pelo menos até que o funcionário não chegue atrasado ou falte com regularidade. Se o indivíduo está sob o efeito das drogas e mesmo assim consegue trabalhar por quatorze horas seguidas com a mesma produtividade, eficiência, bom humor e criatividade, não é visto pela empresa como problema; pelo contrário, é incentivado (SIQUEIRA, 2006).

Uma doença caracterizada pelo modo de vida agitada sem tempo para lazer, fazer refeições ou dormir adequadamente é o estresse, comum entre os trabalhadores pressionados a obterem melhores e maiores resultados. 
Não somos médicos, mas sabemos que a primeira recomendação para solucionar o estresse é mudar o estilo de vida. As empresas fazem, proporcionam ou incentivam essa mudança? Não, apenas criam espaço para a atividade física dentro de suas dependências. Mas exigem que os trabalhadores, principalmente executivos e outros em cargo de direção que levem trabalho para casa, tenham celulares ligados 24 horas, notebooks à tira colo, sem contar que diversos compromissos são marcados fora do horário do expediente, aos sábados, domingos e feriados.

Em relação aos problemas psíquicos dos trabalhadores, os principais são "a dificuldade de relacionamento, a depressão, a ansiedade e a angústia, distúrbios e doenças psicossomáticas, alcoolismos e dependência química, dificuldade de readaptação no trabalho depois de doenças, lesões ou acidentes e tentativas de suicídio" (SIQUEIRA, 2006, p. 178). Aubert (1993, p. 87) afirma que "a neurose de excelência, mostra como certas situações organizacionais provocam em alguns tipos de personalidade, que buscam um ideal profissional elevado e investem na instituição, o estabelecimento de processos neuróticos".

As empresas procuram solucionar esses problemas apenas quando se refletem na produtividade, intermediando os trabalhadores aos serviços psicológicos. Será que essa atitude não seria uma intromissão na intimidade do funcionário? E mais, caso a pessoa busque apoio psicológico profissional fornecido pela empresa, não será ela objeto de discriminação, haja vista que terá de admitir fraquezas em um ambiente organizacional onde todos devem ser heróis? (SIQUEIRA, 2006).

O discurso das melhores empresas para se trabalhar utiliza-se de revistas especializadas que publicam pesquisas que indicam em qual empresa é melhor para se trabalhar, onde as pessoas estão mais felizes, e quais empresas apóiam os recursos humanos.

As empresas desenvolvem práticas gerenciais para que elas alcancem a imagem de preocupadas com seus funcionários, chegam, no discurso, a afirmar que a organização é um local atrativo (SIQUEIRA, 2006), aliado ao fato de que as organizações capitalistas se auto-intitulam como empresas-cidadãs, como lugar da excelência, da juventude eterna, restauradora da ética e da moralidade, como empresa-comunidade (FREITAS, 2000).

Dentre os critérios para se definir se uma empresa é ou não melhor para se trabalhar, Siqueira (2006), enumera oito - salário; benefícios; oportunidades na carreira; segurança e confiança na gestão; orgulho do trabalho da empresa; clareza e abertura na comunicação interna; camaradagem no ambiente de trabalho; e responsabilidade social.

Porém, não podemos deixar de vislumbrar os reais motivos que levam as empresas a investir pesado nestes critérios e 
analisá-los à luz da abordagem crítica que possa compreendê-los como práticas ideológicas, que visam definir códigos de conduta a serem seguidos pelo indivíduo na organização e como processo de mediação, que acabam por exercer papel de grande importância na psique do indivíduo e nas relações de trabalho nas organizações (SIQUEIRA, 2006, p. 186).

Para finalizar, o discurso que impera de que as organizações privadas e seus modelos de gestão devam ser implementados na gestão pública, não devemos esquecer que antes

é necessário, diante deste modelo dominante, buscar alternativas que posam minimizar os efeitos causados pela 1ógica de mercado e pelo imaginário organizacional modernos. É fundamental que os indivíduos compreendam o que há por trás do discurso organizacional, especialmente na prática de gestão de pessoas (SIQUEIRA, 2006, p.)

evitando que se contamine e elimine uma massa crítica que, felizmente, ainda existe no serviço público, que, com certeza, será dizimada caso o gerencialismo consiga seu intento e implante as best practices na esfera pública, sem antes ser objeto de análise profunda e de verificação se serão positivas ou negativas para a administração pública, para os cidadãos e para os servidores públicos.

\section{4 - Modelos de gestão de Pessoas}

A administração de recursos humanos ainda se nutre "dos modelos teóricos do behaviorismo organizacional anglo-saxão e da psicologia comportamentalista americana" (DAVEL; VERGARA, 2008, p. 34), ou seja, vê tudo objetivamente, sem levar em conta as diferenças subjetivas e até objetivas entre os indivíduos.

A visão objetiva na administração dos recursos humanos busca encontrar, através de ferramentas técnicas, formas de administrar o capital humano nas empresas, "visando à maximização dos benefícios econômicos advindos do alinhamento entre o potencial dos empregados e os objetivos empresariais" (DAVEL; VERGARA, 2008, p. 34).

Com a evolução dos conhecimentos da administração dos recursos humanos nos fins dos anos 70, esta deixou de ver as pessoas apenas como custos (DAVEL; VERGARA, 2008) e dividiu a administração de recursos humanos em três abordagens diferentes: funcionalista, estratégica e política.

Enquanto a visão funcionalista é baseada nas tarefas funcionais de treinamento, remuneração, avaliação e analisa o ambiente, planeja as necessidades dos recursos humanos, 
avalia o comportamento, busca aumentar a produtividade e favorecer a vantagem competitiva da empresa, a visão estratégica é a evolução da administração dos recursos humanos quando esta incorpora e é influenciada, nos anos 80, pela visão estratégica das organizações e pelo ambiente de competição internacional e nacional. A visão política busca antecipar as divergências entre o indivíduo e a organização (DAVEL; VERGARA, 2008).

Essa visão objetiva que exalta a administração de recursos humanos recebeu várias críticas, principalmente a que afirma que o desenvolvimento organizacional e a gestão de pessoas esqueceram-se das ciências humanas, haja vista que a obsessão pela eficácia, produtividade, desempenho e rendimento no curto prazo fez com que comparassem os indivíduos a máquinas que se lubrifica através de altos salários, faz-se treinamentos nas selvas ou um final de semana num resort e pronto. (CHANLAT 1994, STEYART; JANSSENS, 1999, apud DAVEL; VERGARA, 2008).

Outras críticas vão de encontro ao paradoxo da gestão de pessoas, que exigem do indivíduo comportamentos dúbios: individualismo e coletivismo, flexibilidade e obediências às regras (OGBONA,1992, apud DAVEL; VERGARA, 2008) versatilidade e adesão a uma forte cultura, empregabilidade já sabendo que a empresa quer diminuir custo, leia-se demissão. Assim, como definiu Legge (1.995, 1989 apud DAVEL; VERGARA, 2008, p. 39), "encontra-se uma incoerência considerável entre a retórica da gestão de pessoas e a realidade de suas práticas".

Em contraponto à forma objetiva de administração de recursos humanos que enxerga as pessoas apenas sob o prisma de custos, temos a gestão de pessoas que reconhece que estas têm suas subjetividades, que para Faye (1991, apud DAVEL; VERGARA, 2008, p. 43), é a "interioridade da pessoa, a singularidade e a espontaneidade do eu, enfim, ela e tudo aquilo que constitui a individualidade humana é que sedimenta todo e qualquer conhecimento possível".

As empresas que de fato enxergam as pessoas não apenas como um recurso ou custo, como fazem em seus discursos organizacionais, para as empresas que acreditam ser as pessoas imprescindíveis no processo de modernização das empresas, "parece evidente a necessidade de gestores renovarem sua forma de atuação, enriquecendo sua compreensão sobre a complexidade das individualidades e de experiência vivida em coletividade" (DAVEL; VERGARA, 2008, p. 42), ou seja, os gestores precisam estar atentos à subjetividade das pessoas.

Temos várias teorias de recursos humanos que têm o foco na subjetividade das pessoas, as principais são a do conhecimento-poder, que investe na relação 
conhecimento/poder, desenvolvida a partir da obra de Focault. O construtivismo de PiganiolJacquet busca compreender a formação dos sistemas de gestão de pessoas, desde o nascimento até a sua efetiva colocação em prática ou não. As técnicas de gestão dependem do contexto histórico, por isso é um contructo social. O estruturacionista foge do paradoxo entre o objeto societal e o sujeito individual, haja vista que a noção de ação e estrutura sobrepõe-se uma a outra, por intermédio de uma relação dialética (DAVEL; VERGARA, 2008, P. 49).

Por fim, acreditamos que a administração dos recursos humanos ou gestão de pessoas não deve ser responsabilidade de um departamento; pelo contrário, é responsabilidade de todos os gestores que "devem perseguir objetivos que criem vantagens competitivas para a organização por meio de pessoas e iguais vantagens para as pessoas" (DAVEL; VERGARA, 2008, p. 50) e que a gestão de pessoas seja

concebida como uma mentalidade, uma forma constantemente renovada de pensar a atuação e a interação humana na organização, reconhecendo o que é uno e múltiplo no ser humano, mostrando como todo fenômeno estudado e perpassado pela subjetividade, reafirmando o papel da pessoa, de sua experiência e do simbó1ico nas organizações e, ao mesmo tempo, restituindo a pessoa a seu quadro sociohistórico (FERRIS et al, 1999 apud DAVEL; VERGARA, 2008, p. 50). 


\section{3 - METODOLOGIA}

Os discursos em gestão de pessoas disseminados pelos defensores do gerencialismo ou da cultura do management, a cada dia que passa, influenciam mais e mais a sociedade.

A gestão pública sofre por dois lados: primeiro, pela influência da cultura do management; e, segundo, pelo próprio desgaste da burocracia perante a sociedade.

No presente estudo, essas modalidades foram divididas da seguinte forma: do modelo burocrático ao modelo gerencial (CHANLAT, 2002; PAULA, 2005) o gerencialismo e seus discursos (ENRIQUEZ, 1997; FREITAS, 2000; GAULEJAC, 2007; PAGÈS et al, 1993; PAULA, 2005; SIQUEIRA 2006) e discursos em gestão de pessoas (FARIAS, 2007; SIQUEIRA, 2006; PAGÈS et. al, 1993).

\section{1 - Tipo de Pesquisa}

Vergara (2000) indica dois critérios para se realizar uma pesquisa científica: quanto aos fins: exploratória, descritiva, explicativa metodológica, aplicada e intervencionista; e quanto aos meios: pesquisa de campo, de laboratório, documental, bibliográfica, experimental, ex post facto, participante, pesquisa-ação e estudo de caso. A presente pesquisa será quanto aos fins, descritiva, e quanto aos meios, bibliográfica, documental e formal.

Descritiva porque visa caracterizar a população pesquisada, em especial suas percepções sobre o tema.

Na fundamentação teórica, foi utilizada a pesquisa bibliográfica, tendo como fontes de conhecimento livros, monografias, revistas, artigos, revistas científicas e meios eletrônicos.

Os dados desta pesquisa foram coletados, por meio de entrevistas individuais com os indivíduos pesquisados, ou seja, coleta formal de dados, considerado o mais adequado para uma pesquisa qualitativa.

Houve ainda uma pesquisa documental, em razão de as informações internas do órgão estarem expressas basicamente em lei, regimento interno e divulgações pelo sistema interno de informações e dados (intranet). 
Foi pesquisado um órgão público da esfera judicial federal, localizado na região Centro Oeste, com dezoito anos de existência e reconhecido pela quantidade de julgados e pela busca em se modernizar.

Seu corpo funcional é de aproximadamente 2.650 funcionários, sendo que deste total, 1.245 têm curso superior, 813 têm especialização, 42 são mestres e 7, doutores. Acredita-se que o número de especialistas, mestres e doutores aumente bastante, haja vista que recentemente foi aprovada lei no Congresso Nacional que incentiva esses cursos com adicionais sobre o salário.

\section{2 - População e Amostra}

A pesquisa foi constituída por entrevistas realizadas com quatro profissionais da organização pesquisada, que têm experiência na gestão de pessoas na Administração Pública Federal, todos com pelo menos cinco anos de atuação na área e que influenciam ou já influenciaram a formulação de políticas de recursos humanos na organização.

As pessoas foram selecionadas por procedimentos não probabilísticos, haja vista que não foi utilizado nenhum procedimento estatístico. O meio da acessibilidade foi o escolhido.

\section{3 - Instrumento}

“A entrevista representa um dos instrumentos básicos para a coleta de dados” (VERGARA, 2000 p. 33). Essa técnica permite complementar e apronfudar as questões levantadas por outros meios, permitindo receber informações mais pontuais e espontâneas do entrevistado. Obviamente, para isso, o entrevistador precisar ter um comportamento ético, respeitar horários e o entrevistado e, acima de tudo, garantir sigilo e anonimato em relação ao mesmo (VERGARA, 2000).

A habilidade do entrevistador é de suma importância para o sucesso na obtenção dos dados, e saber interpretar sinais corporais, entonações de voz, expressões faciais, hesitações é fundamental para captar as informações não ditas.

Torna-se importante um roteiro ou guia para fundamentar as perguntas e, sobretudo, auxiliar na condução da entrevista, evitando fuga do foco. 


\subsection{1 - Roteiro de Entrevista}

Como foi salientado anteriormente, a técnica utilizada para coleta de dados foi a entrevista semi-estruturada, tendo em vista que se trata de instrumento dinâmico, permitindo a utilização de um roteiro flexível, aprofundamento e adaptações nas informações coletadas.

Nesse sentido, o roteiro de entrevista foi elaborado com base nos seguintes aspectos que norteiam as questões a serem colocadas aos entrevistados:

1 - Definição de burocracia;

2 - A burocracia mais atrapalha ou mais ajuda;

3 - Definição de gerencialismo, modelo gerencial;

4 - Opinião sobre a mudança do modelo burocrático para o modelo gerencial no serviço público;

5 - Crença que o modelo gerencial ajudará a gestão de pessoas do serviço público a se tornar moderna;

6 - Resistência em implantar o modelo gerencial no serviço público;

7 - Reconhecem alguma prática de gestão de pessoas com traços de gerencialismo no serviço público (melhores empresas para se trabalhar, gestão por competências, benchmarking, melhores práticas, empowerment, comprometimento, educação corporativa);

8 - Reflexos na gestão de pessoas com a importação/implantação de práticas gerenciais no serviço público?

9 - Produção dos serviços com as práticas gerenciais;

10 - Pressão sobre servidores por melhores resultados;

11- Problemas com adaptação às ferramentas gerenciais;

12 - Melhorias nas condições de trabalho;

\section{4 - Procedimentos}

Os dados foram coletados por meio de entrevistas individuais semiestruturadas.

Para realização das entrevistas foi mantido contato prévio com os entrevistados, visando agendar datas. Optou-se por deixar o entrevistado definir dia, hora e local que mais se adequava ao seu dia-a-dia. 
No início da entrevista, foi lido um texto com a intenção de deixá-lo à vontade e ciente do que se tratava, além de garantir que a entrevista teria caráter sigiloso e o fim específico a que se destinava, conforme a seguir:

- Esta entrevista tem caráter sigiloso, seu conteúdo será utilizado exclusivamente para monografia de conclusão do primeiro Curso de Especialização em Gestão Judiciária, coordenado pelo Programa de Pós-Graduação em Administração da Universidade de Brasília.

- Bom Dia. Esta entrevista tem a intenção de captar as impressões e percepções que o senhor/senhora tem acerca de alguns itens relevantes para a gestão de pessoas, por isso pedimos que todas as suas respostas tenham como foco principal o tema gestão de pessoas, o(a) senhor(a) autoriza a gravação desta entrevista?

\section{5 - Resultados}

Acreditamos que os núcleos de sentido abaixo proporcionaram a obtenção dos dados necessários para responder aos objetivos do estudo.

1 - Transição Burocracia x Modelo Gerencial na Ótica dos Gestores de Pessoas;

2 - Gestão Pública e Privada: Diferenças e Semelhanças na Percepção da Gestão de Pessoas;

3 - Resistências, Pressões, Discursos Organizacionais em Gestão de Pessoas e Conseqüências para os Servidores Públicos. 


\section{4 - DISCUSSÃO}

\section{Categoria 1}

Transição Burocracia x Modelo Gerencial na Ótica dos Gestores de Pessoas.

\section{Descrição:}

Estamos vivenciando um processo de mudança forçada que obriga os administradores públicos a apresentarem resultados condizentes com os anseios da população. O Poder Judiciário, no momento, é questionado por sua morosidade em resolver processos que a cada dia chegam às varas em maior número esperando por soluções.

A opinião pública impõe mudanças e vários gestores públicos, inclusive do Poder Judiciário, são tentados e incentivados a implantar ferramentas e técnicas que, pelo menos na mídia especializada, são consideradas modernas e revolucionárias. Caso optem por não implantá-las, são considerados arcaicos e bastante criticados.

Dentro da ótica de que qualquer mudança deva ser precedida por uma profunda reflexão, busca-se, nessa categoria, analisar até que ponto os gestores responsáveis pelas políticas de recursos humanos na organização pesquisada dominam os conceitos das formas de dominação acima e como percebem a transição, que, em certos aspectos, mais parece uma justaposição entre a burocracia e o modelo gerencial - de forma positiva ou negativa.

Vale lembrar que toda e qualquer forma de poder e dominação existente, seja no ambiente familiar, seja num clube social ou igreja, traz junto a si coisas boas e más; por isso, a intenção é identificar nas falas as percepções sem emissão de juízo de valor.

\section{Narrativas e Discussão}

Descreveremos abaixo as falas extraídas das entrevistas realizadas com os servidores selecionados por terem experiências em gestão de pessoas na esfera pública e outros que também têm na iniciativa privada. Apenas para esclarecer, não esperávamos definições ao pé da letra, e sim como as pessoas enxergam e percebem as conseqüências da burocracia e do gerencialismo no trabalho por eles realizados.

"burocracia no serviço público, ela pode ser uma burocracia saudável desde que ela reflita é... realmente um cuidado que precisa se ter quando está lidando com aquilo que é público, que é pro coletivo". R2 
"passa muito pela questão do cuidado que você tem que ter no momento de tomar as decisões”. R2

"não tem como você extirpar totalmente o modelo burocrático do serviço público, não tem como você abrir mão já que a burocracia efetivamente tem uma razão de ser” $R 2$

Nessas falas, selecionamos as que, de certa forma, trazem aspectos positivos da burocracia. Foi minoria e longe de ser unânime entre os respondentes, mas podemos perceber que as falas associaram a burocracia a uma forma de dar mais transparência aos procedimentos públicos.

Ora, essa preocupação é válida, haja vista o Poder Judiciário, mais que qualquer outro poder ou função pública, necessitar da legalidade, ou melhor, sobreviver dela; logo, a burocracia tem as características para resguardar a atividade judicante dos tribunais, tais como o cuidado para que as normas sejam formais, expressas em códigos ou lei e alcance a todos, universais, já que todos devem ser iguais ou alcançáveis pelas leis, e impessoais, já que se ligam aos fatos e atos judiciais, e não a pessoas.

Essa preocupação, ou melhor, essa opinião, vai de encontro à de Azevedo e Loureiro (2003), uma vez que estes acreditam que a "administração burocrática é o modelo mais compatível com uma ordem republicana” justamente pelos fatos acima descritos.

A seguir, reproduziremos algumas falas que tratam a burocracia de forma negativa.

"eu entendo que ela mais prejudica se considerarmos que o gestores não utilizam a burocracia no sentido mais adequado, né acho que é um uso inadequado da burocracia que a torna prejudicial no andamento dos serviços públicos”.R2

Nessa narrativa, não temos necessariamente uma negativa pela burocracia, mas sim a forma como ela é usada. A falha não estaria nela, e sim nas pessoas. A seguir, temos outras narrativas nessa direção de responsabilizar as pessoas.

"É todo processo de trabalho, eu tô falando de processo interno tá, que você cria de forma que vai havendo dificultadores para a concretização dos resultados ou para entrega do produto ou do serviço, isso é burocracia” $R 4$

Nessa fala, o respondente afirma que o processo de trabalho é criado a partir da burocracia e criam-se dificultadores para o trabalho, "isso é burocracia”. A burocracia, a princípio, foi pensada como uma forma de dominação que deveria combater e dificultar as práticas do clientelismo e do patrimonialismo; hoje está sendo usada mais para atrapalhar o trabalho. 
“Atrapalha, (burocracia) sem dúvida, sem dúvida atrapalha, por que é... são dentro destes processos internos o que acontece o... cria-se normativas em que as pessoas vão usar isso como argumento para impedir o resultado ou o alcance do resultado ou a entrega do serviço.” $R 4$

Não podemos nem queremos desmerecer o sentimento de que a burocracia atualmente seja usada como cortina para que alguns servidores se escondam atrás dela. No nosso entendimento, essa é apenas uma das disfunções da burocracia e atrapalha bastante.

Análise diferente, mas não contrária à narrativa, tiveram Mota e BresserPereira (2.004, apud MATOS; LIMA, 2007), quando afirmam que, devido à rigidez, ao formalismo e à impessoalidade, os funcionários públicos, ao invés de utilizarem-se deles, como na narrativa do respondente, pelo contrário, criam ou desenvolvem uma organização informal para vencer essas, que, para eles, é uma disfunção da burocracia. Ou seja, de qualquer forma a pessoa adapta a seus interesses.

“(...) cria-se normativas em que as pessoas vão usar isso como argumento para impedir o resultado ou o alcance do resultado, ou a entrega do serviço."

Não raro, quando vamos a uma repartição alguns funcionários públicos se escondem atrás de normas que não se aplicam àquele caso concreto. Casos, por exemplo, que se resolveriam na hora, como a norma fala, em três dias úteis... Infelizmente isso acontece.

Outra narrativa que ratifica a avaliação negativa dos funcionários públicos: “eu trago, na minha opinião, coisas negativas para o serviço público, posturas de servidores, de pessoas que acham que estão aqui para aproveitar a vida e não para trabalhar”.R3

Essa fala retrata bem como alguns servidores são vistos pelos próprios colegas de trabalho - o que dirá pela população. Chanlat (2002) afirma que nos últimos vintes anos estes sofrem os efeitos dos discursos dos defensores do modelo gerencial que afirmam que são ineficientes e que alguns ainda escondem essa condição por vergonha.

Sabemos por Faria, Schimit e Meneguetti (2.007, p. 71) que o indivíduo busca também a aceitação social como uma forma de legitimação. Porém, os próprios colegas de trabalho os julgam mal, como já referenciado.

Outra anomalia que o respondente cita se relaciona aos caminhos, às idas e vindas que vários processos administrativos percorrem.

"nos processos administrativos, por exemplo, que agente trabalha aqui dentro do órgão, você vê aquele famoso "ao" despacho né, "ao" fulano, "ao" beltrano, "ao" sicrano, ai fica "ao ao" né, fica dando volta e isso é burocracia, e é trabalho." R4 
Vários processos de trabalho, em sintonia com a opinião da entrevistada, poderiam ser resolvidos sem a necessidade de tantas voltas, e novamente a burocracia é associada às voltas intermináveis que processos dão antes da resolução do problema.

“e melhorar os processos internos, ou seja, desburocratizar, tornar o processo de trabalho transparente, isso traz uma motivação sem precedentes, e nós vamos chegar lá.”R4

Por fim, o respondente profetiza: “(...) desburocratizar (...) e nós vamos chegar lá”. Talvez por isso Renaut (2005) afirma que uma das formas de melhorar a administração no Judiciário seja o financiamento de projetos que visem à desburocratização.

Esse é o sentimento que as pessoas fazem a respeito da burocracia. É bastante influenciado tanto pela realidade dos processos dentro dos órgãos quanto pela indústria do management.

A realidade dos processos foi, a nosso ver, bem retratada nas falas selecionadas, mas não podemos simplesmente associá-la à burocracia.

Embora muitas vezes, ou melhor, nas maiores das vezes, os respondentes tenham uma conotação negativa da burocracia, inclusive associando às práticas que denigrem o serviço público, temos de ter consciência que não se trata de privilégio único da burocracia essas anomalias. Conforme afirma Azevedo e Loureiro (2003), a burocracia em vários países, inclusive no Brasil, nem sequer foi concretizada e o clientelismo e patrimonialismo ainda hoje fazem parte da dominação. Quando Weber propôs a burocracia queria justamente combatêlos.

Muito interessante nessas falas é que ninguém tentou diretamente conceituar a burocracia, falou efetivamente das conseqüências que ela traz para o serviço.

A princípio, poderíamos afirmar que a indústria do management está sendo efetiva ao tentar impor suas ferramentas e práticas. Basta lembrar que os livros dessa indústria abarrotam as livrarias no mundo inteiro, pois apresentam soluções maravilhosas. O interessante é que eles vêm sempre na forma de parábolas: Lideranças bíblicas, como administravam os astecas e os mais etc. Vale lembrar que para Faria (2007) esses livros vendem bastante porque as pessoas não têm tempo ou não querem pensar, embora nesta instituição pesquisada percebêssemos em várias falas, alheio à sobrecarga de trabalho que recai sobre os servidores públicos de uma forma geral (CHANLAT, 2002), as pessoas estão refletindo sobre o assunto.

"bom eu tenho uma imagem leiga, eu acho de burocracia né, é... burocracia a primeira coisa que me vem à mente é algo ruim. negativo é... complicado, mas que depois de uma experiência no setor público eu vejo que é necessário." R3 
"olha se agente for pensar no trabalho assim mais atrapalha, mas se agente for pensar nas implicações que esse trabalho tem e na... e na organização e no controle que você precisa ter das ações dos agentes públicos ela é mais necessária”. R3

Apesar da afirmação de Pagès et al (1993), de que hoje a sociedade possui mais informações e anos de estudo e, mesmo assim, os trabalhadores serem mais alienados que de gerações passadas, vemos colocações das pessoas entrevistadas que indicam que a organização tem pessoas dadas às reflexões. Apontam e não negam os problemas, mas refletem e entendem a necessidade e, como a seguir, já estão pensando numa nova forma de administração pública.

"não entendo que você possa adotar cem por cento desse modelo administrativo, gerencial no setor público, eu acho que existe sim é... parte importante que não podemos abrir mão tanto do modelo burocrático quando do modelo gerencial." $R 2$

O respondente diz que nem uma nem outra forma é suficientemente boa ou ruim para a administração pública, talvez para ela até se completem.

Outra narrativa bastante interessante e que mostra que felizmente ainda temos pessoas preocupadas e querendo o melhor para a administração pública:

“mas hoje o que eu vejo, talvez seja o maior problema na administração pública, e que isto precisa ser saneado muito, é a existência ainda de práticas muito clientelistas, é isto que nos atrapalha, quando agente olhar um pouco mais, e tentar alguma coisa perto da meritocracia, a coisa vai funcionar muito melhor.” R1

Infelizmente, nem com a administração burocrática nem com a implantação do modelo gerencial na administração pública essas práticas foram sanadas. Vale lembrar que a burocracia, segundo Azevedo e Loureiro (2003), ainda não foi implementada e a reforma gerencial proposta por Bresser-Pereira, através do Plano Diretor da Reforma do Estado, conseguiu acabar com as “práticas muito clientelistas”. Também percebemos essas práticas negativas acontecendo, embora acreditemos que a burocracia tem, pelo menos nesse aspecto, melhores condições para combatê-los.

A afirmação do respondente que acredita que se tivéssemos "alguma coisa perto da meritocracia, a coisa vai funcionar melhor” já traz em si uma das principais características da burocracia, a meritocracia (VERGARA, 2003), que, se no entender do entrevistado, estivesse implementada, "a coisa vai funcionar muito melhor”, a administração estaria num nível superior ao de hoje. 
De outro lado, o respondente teve a intenção de afirmar que devemos ser mais justos, haja vista que o patrimonialismo divide o poder de forma paternalista para os amigos e familiares. O clientelismo funciona como uma troca. A meritocracia, pelo contrário, dá o poder a quem tem competência técnica, que, para Morgan e Enriquez (1996, 1991 apud SIQUEIRA, 2006), é uma das principais formas de poder e de mais fácil identificação presente nas organizações, já que vem do cargo e não das pessoas que os ocupam - impessoal. O respeito é do cargo, não de quem está nele.

\section{Categoria 2}

Gestão Pública e Privada: Diferenças e Semelhanças na Percepção da Gestão de Pessoas.

\section{Descrição:}

As ferramentas do modelo gerencial a cada dia estão mais presentes na gestão pública. Na iniciativa privada essas práticas estão voltadas conceitualmente para o lucro.

Essas ferramentas atendem aos anseios dos administradores públicos que buscam efetividade em suas políticas? Ou será que provocará uma mudança de paradigma? Mudará o éthos dessa gestão e será regido pelo dos negócios? (CHANLAT, 2002).

Nesta categoria, busca-se analisar a percepção dos gestores sobre as diferenças das práticas da gestão pública e privada. É a mesma sistemática? São exigidos os mesmos requisitos de competência e posicionamento dos servidores públicos?

\section{Narrativas e Discussão:}

Administrar uma empresa pública é o mesmo que uma empresa privada? Essa pergunta encontra-se sem resposta. Até hoje não existe consenso sobre a melhor forma de administrar uma entidade pública.

Com a ascensão do gerencialismo, o modelo gerencial vem sendo imposto às empresas públicas, haja vista que o discurso deste é baseado na crítica da burocracia e que, utilizando as práticas e ferramentas da iniciativa privada, a administração pública exibiria melhores resultados (Paula, 2005).

"existe uma ciência chamada ciência das administrações ela não tem conceitos diferentes, a gente tem que práticas às vezes que são diferenciadas, mas dentro de meios condizentes”R1

Essa fala indica que a administração, ou melhor, a Ciência da Administração é igual tanto na esfera pública tanto na privada. De fato, temos "práticas às vezes que são 
diferenciadas”, e tem que ser mesmo, haja vista o objeto da administração pública ser totalmente diferente do da privada.

Enquanto o foco do gestor privado é o lucro e os meios de se organizar para tal, o gestor público se foca nas políticas públicas, ou seja, busca meios para que os cidadãos possam usufruir seus direitos e participem das formulações destas.

Nas narrativas a seguir, temos essa idéia corroborada; vejamos:

"o momento em que estou atuando como servidor público é... a minha postura é diferente quando eu tô atuando numa empresa privada”. R2

“mas há que se ter um certo cuidado, existem as prática adotadas (...) nas empresas privadas é... e que não faz sentido você adotar nas empresas públicas exatamente por ser outro contexto”. R2

“(...) realmente um cuidado que precisa se ter quando está lidando com aquilo que é público, que é pro coletivo”. R2

Chanlat (2002) foi ao cerne da questão quando afirmou que a ética do serviço público obriga o funcionário público a ser impessoal e isso ajudaria a consolidar a democracia e que, com a introdução do modelo empresarial nessa esfera, nitidamente personalista, tornaria a administração pública do mesmo modo, ao contrário do que se pressupõe e espera de uma democracia, onde o público é para todos.

De acordo com Pagès et al (1993), as organizações modernas incentivam o sucesso individual em detrimento da solidariedade, e o executivo nas empresas pensa em primeiro, segundo e terceiro lugar nele mesmo, ou seja, tudo, a partir desse momento, partiria da premissa dos negócios.

Outra característica da administração pública é que ela visa ao coletivo, não a uma só pessoa ou grupo. O retorno dos investimentos não é medido nem esperado apenas em cifras, e sim na melhoria da qualidade de vida dos cidadãos. A empresa privada visa, em primeiro lugar, ao retorno do investimento em lucros e dividendos aos acionistas e, depois, à satisfação dos seus clientes. Quando evoca um discurso de cidadania, nada mais quer que a legitimação social ou marketing para aumentar vendas.

Dentre outros objetivos da reforma gerencialista proposta por Bresser-Pereira (1998 apud PAULA, 2005), está assegurar a democracia através da prestação de serviços orientados para o 'cidadão-cliente', semelhante ao que as empresas fazem ao evocar o discurso da satisfação total dos clientes. Por isso, seria preciso deslocar o foco do processo para o cliente.

“quando você desloca um foco no processo e passa o foco pro cliente” R1 
"acho que a gente não tem que ficar no efeito comparação do que é privado e do que é público, não é?”(...) Tem cliente lá,(administração privada) tem cliente aqui (administração pública)” R1

Quando o cidadão é tratado como cliente, ele perde a noção de responsabilidade que todos nós, cidadãos, temos que ter perante a sociedade, perante os menos favorecidos. Ele passa a exigir o produto ou a prestação do serviço, se importando apenas com isso. Até pagamentos de impostos passam a ser um fardo pesado, e não um orgulho (GAULEJAC, 2007). Não estamos aqui nos referindo à carga tributária, e sim ter consciência que, para se manter um Estado, é necessária a contribuição de todos, seja através de tributos, seja através da participação política.

Exatamente na contribuição reside o problema, pois, com o estado gerencial, deixo de ser cidadão e me transformo em cliente, pronto a exigir a prestação do serviço tal qual prometido. E minha responsabilidade perante a Nação? Passo a recorrer aos políticos para reclamar pela solução dos meus problemas, e não para fazer parte das decisões do meu bairro, da minha cidade, do meu estado, enfim da nação.

Talvez esse seja um componente a mais, não único, da falta de cuidado que a população tem com os bens públicos em geral. Ela não vê aquilo como seu, sente apenas que paga para usar e pronto. Além disso, existe aquela famosa frase: “eu detesto política”. O cidadão tem que participar, criticar, votar, dar sugestões, reclamar no sentido de cidadão, e não apenas como cliente ou consumidor; enfim, deve assumir o papel que é seu de direito: ator principal nessa peça de construção de um Estado melhor através da cidadania.

Quando clientes, raciocinamos como tal, cobramos a prestação do serviço, reclamamos se estiver ruim, não procuramos saber por que está ruim nem interferimos na decisão. Não procuramos saber por que, por exemplo, preferiu-se investir em estradas, ao invés de em hospitais. Se pensarmos como cidadãos, vamos, democraticamente, exigir que o orçamento seja alocado onde a maioria julgar prioritário.

Paula (2005) afirma que uma das falhas do modelo gerencial reside justamente na incapacidade de dar respostas à questão sociopolítica.

Apenas ratificando a questão de que a administração pública é diferente da administração privada e de transformar o cidadão em cidadão-cliente, conforme proposto por Bresser-Pereira, observe-se a fala do respondente abaixo relatando as dificuldades em implantar as técnicas de gestão da iniciativa privada.

“Olha eu creio que sim, (o gerencialismo trará modernidade para a gestão de pessoas) por que a... obviamente com as adaptações né... acho que o que impede que seja efetivamente 
incluindo dentro do serviço público, são dois aspectos: uma é a própria cultura do serviço público, e outra coisa é essa necessidade de controle que existe para que você dê respostas a sociedade das suas ações, é que dificulta um pouco a implementação dessas técnicas novas. "R3

Quando o respondente afirma que uma das dificuldades para implantar essas novas técnicas de gerenciamento reside no controle que o administrador público precisa ter para que possa dar respostas à sociedade de suas ações, ele, a nosso ver, está falando da questão de que a sociedade, os cidadãos querem respostas e prestações de contas não só a nível econômico, mas também e principalmente em nível de políticas públicas.

Se a narrativa abordasse apenas as questões econômico-financeiras, não existiriam diferenças entre o gestor público e o privado e a implantação não enfrentaria essas resistências; pelo contrário, seriam iguais tanto nas gestões públicas quanto nas privadas. Como já mencionado, o gestor privado presta contas com lucros perante os acionistas, que, por sua vez, se preocupam com os dividendos que receberão. O gestor público, além de buscar a economicidade, tem de aferir se as políticas públicas foram, de fato, efetivas e atenderam às necessidades dos menos favorecidos e distribuíram cidadania.

Com relação às diferenças entre gerir pessoas na iniciativa privada e pública, segue transcrição da narrativa de um entrevistado.

“Muito mais gostoso (gerenciar pessoas na iniciativa privada) É, assim o trabalho é intenso também, tanto quanto é aqui, a pressão é muito maior né, mas em compensação as pessoas elas são mais... elas não têm essas nuanças de resistência, como tem no serviço público né, a... o servidor público ele quer colocar suas idéias, ele quer conquistar espaço, ele quer... mesmo por que ele é uma pessoa já de um grau superior, ele é uma pessoa já mais especializada. Na empresa privada existe essa rede especialidade e até são muito respeitados dentro da organização, mas o... a... dependendo do tipo de negócio da empresa privada ela absorve muita mão de obra ainda de nível de segundo grau, nível de primeiro grau, como é o caso das construtoras, então é muito mais fácil você trabalhar com eles, para que eles obtenham resultados, eu acho... eles respondem mais rápido, as pessoas respondem mais rápido." $R 4$

O respondente deixa claro que é muito mais gostoso gerenciar pessoas na iniciativa privada, embora admita que o trabalho seja intenso e a pressão na iniciativa privada é muito maior "Muito mais gostoso (gerenciar pessoas na iniciativa privada) É, Assim o trabalho é intenso também, tanto quanto é aqui, a pressão é muito maior (...)”. 
Ao analisar o restante da fala, buscando o que justificaria essa resposta, encontramos a primeira que residiria na questão “mas em compensação as pessoas elas são mais... elas não têm essas nuanças de resistência, como tem no serviço público (...)”, ou seja, apesar do ritmo de trabalho e da pressão maior, em compensação não teríamos na iniciativa privada resistência.

E elas não têm, segundo o respondente justamente porque “o servidor público ele quer colocar suas idéias, ele quer conquistar espaço, ele quer... mesmo por que ele é uma pessoa já de um grau superior, ele é uma pessoa já mais especializada”.

Geralmente na administração do serviço público temos a obrigação de sermos democráticos em nossas decisões. Necessariamente precisamos legitimá-las. Estamos numa democracia, não há que se falar em autoritarismo na esfera pública, ou então viveríamos ainda numa ditadura.

Na iniciativa privada não. A ditadura é a dos lucros. Um executivo não precisa colocar suas decisões em discussões com subordinados - ele o faz apenas se quiser. Ilustrando, temos a seguinte fala:

“O gestor na empresa privada ele tem condições de dizer e definir quem ele vai captar, quanto ele vai gastar, como ele vai distribuir esse orçamento entre as pessoas, quanto ele vai gastar em capacitação e com material, e com isso e com aquilo, o que ele vai botar o que ele vai tirar, se ele precisa de alguém ele vai ao mercado e busca, se ele quiser vender a empresa” R3

Podemos notar que, de fato, quem manda na empresa é o dono ou seus executivos. Mas o que justifica os empregados da iniciativa privada não possuírem "essas nuanças de resistência” seria só o ambiente democrático que se tem no serviço público ou seria a existência de profissionais mais especializados nessa esfera? Pode até ser, mas se os empregados da iniciativa não têm esse grau superior, eles teriam, mesmo assim, idéias que seriam facilmente refutadas pela rede de pessoas capacitadas que a empresa privada mantém.

O discurso do "ganhe com a participação", segundo Siqueira (2006) estimula os empregados a participar das decisões e das resoluções dos problemas através de idéias, inclusive do pessoal do chão de fábrica. Nesse contexto, os trabalhadores da construção civil poderiam participar e ajudar a decidir a melhor forma de realizar os trabalhos, poderiam até resistir às mudanças e não se engajarem nelas.

Em outra fala, acreditamos que, de fato, o que faz com que os trabalhadores da iniciativa privada não tenham nuanças de resistência seja o medo da demissão. O servidor público, apesar de constar do Plano Diretor da Reforma a flexibilização, ou seja, fim da 
estabilidade, ainda a possui; por isso, ele pode e deve contribuir para o aperfeiçoamento democrático e colocar e buscar seu espaço através das idéias.

“a vantagem que eu vejo no serviço público é que você não sofre uma pressão tão grande quanto na empresa privada, imagino que se agente sofre por pressão agente não tem noção do que é pressão, por que pressão sim sofre quem tá em uma empresa privada onde o dia-adia é o que mantém ou tira ele daquele lugar, e se ele sair daquele lugar ele é...vai pra rua”

Dentre as formas de poder existentes para Siqueira (2.006) está o da possessão dos meios de sanção, que poderia ser explicado pelo poder que o dono ou executivo da empresa tem para tirar ou colocar alguém daqui e colocar acolá ou na rua.

Logo, acreditamos que o principal motivo que justifica ser melhor gerir pessoas na iniciativa privada seja exatamente este: o poder que ele tem de dizer: ou faz ou vai pra rua. Pode até não ser dito literalmente, mas essa frase faz parte, infelizmente, da realidade organizacional.

Por fim, acreditamos que de fato existem diferenças e semelhanças entre administrar no setor público e privado, embora não devamos esquecer-nos das peculiaridades de cada um. E mais, os administradores do setor público não podem se apartar da busca e da reflexão por uma administração pública melhor, já que ainda não foi encontrada, nem no Brasil nem no resto do mundo, a melhor forma de fazê-la.

\section{Categoria 3}

\section{Resistências, Pressões, Discursos Organizacionais em Gestão de Pessoas e Conseqüências para os Servidores Públicos.}

\section{Descrição}

A burocracia atualmente ainda é a forma de dominação predominante, embora não única na administração pública. O modelo gerencial, bastante incentivado, inclusive objeto de um Plano Diretor, ainda não alcançou os objetivos de sua reforma, nem tão pouco substituiu a burocracia. Antes vemos a convivência nada harmônica entre ambas. Por meio de práticas e ferramentas, o modelo gerencial vem dividindo com a burocracia a gestão nos órgãos públicos.

Os discursos de gestão de pessoas, com o foco no modelo gerencial, estão presentes na Instituição pesquisada, bem como as conseqüências e posicionamentos das pessoas frente a essas mudanças. Vale lembrar que estamos num campo de suposição, pois a 
percepção pesquisada se restringe aos gestores relatarem as conseqüências que acreditam que se dá ou se dará sobre outras pessoas, embora saibamos que não deixará de refletir nas verbalizações impressões pessoais sobre seu próprio comportamento.

\section{Narrativas e discussão}

Uma das vantagens para as organizações investirem pesado na gestão de pessoas está no fato de que esta é a mediadora entre os objetivos organizacionais e os indivíduos que proporcionam, em ambientes de mudanças, muitas resistências. De uma forma natural, as pessoas resistem principalmente quando julgam que serão prejudicadas em seus direitos e status.

Nesse ponto, ou seja, na atuação institucional da gestão de pessoas enfrentando as resistências e os meios e ferramentas que utiliza visando à melhora da produtividade (pressão), acreditamos que podemos identificar os discursos organizacionais presentes na instituição e a forma como se comporta o trabalhador.

A seguir, transcrevemos entrevistas as quais tratam das resistências dos indivíduos e a atuação da gestão de pessoas como mediadora desse conflito de interesses. “a resistência é muito grande, e quando a resistência... as pessoas acham que qualquer tipo de mudança no serviço público vem pra prejudicar” R3

“Em primeiro lugar agente... agente... no início as pessoas estranham, resistem, depois elas vão se alinhando, e depois que elas vêem que agente tá plantando excelentes resultados” R4 “não acredito (que vá haver resistência), acho que as pessoas é....estão mais interessadas nos resultados, né que na aplicação de um modelo ou outro traz, do que efetivamente se posicionar é... de forma resistente. Eu acho que a resistência, você verifica essa resistência quando você não vê resultado na aplicação do modelo.” R2

"então a resistência ela sempre existe, mas por que a pessoa ainda não conhece a ferramenta, não conhece o método, a partir do momento que começa a conhecer, essa resistência dilue.” R4

“nós temos que trabalhar as resistências com a implantação desses novos modelos, dessas novas ferramentas, que se você trabalha de uma forma que o teu discurso seja coerente com a sua ação, ou seja, você vai para frente de um tribunal cheio e diz o seguinte: 'você vai ser mais feliz, vai trabalhar melhor e vai estar mais motivado' e o tribunal vai em contra partida reconhecer seu desempenho melhorado, seguramente ele paga pra ver, ele paga pra ver, e no momento que experimenta uma situação em que de fato tem ganho pessoal e profissional ele não quer voltar atrás é como uma ponte que explodiu por trás delas, então na verdade eu 
acho que, eu não tenho notícias (de resistências), eu tenho notícia de resistências iniciais que nos trabalhamos e depois a coisa anda." R1

Nessa fala, percebe-se claramente que a gestão moderna de pessoas de fato funciona como mediadora da organização e como trabalhará para modificar as resistências iniciais e transformá-las em força produtiva.

Pagès et. al (1993) já indicavam que modernamente a gestão de pessoas já não funciona apenas como mediadora econômica, tem também uma função ideológica, e institucionalmente é bastante requisitada em processos de mudanças organizacionais, em especial os programas ligados à qualidade total e à reengenharia (CURADO, PEREIRA FILHO E WOOD JR., 1995), ou seja, ela não é chamada para implantar a técnica em si, ela é requisitada para fazer indivíduos conforme as diretrizes da organização.

“(...) no início as pessoas estranham, resistem, depois elas vão se alinhando,...”

A gestão de pessoas diferencia-se na forma de atuação justamente por ter o poder de influenciar o comportamento das pessoas e buscar que a organização funcione de modo eficaz (BRABET, 1993 apud DAVEL; VERGARA, 2007) obviamente em busca de reduzir custos e aumentar os lucros. Na narrativa a seguir, percebemos, além dessa busca, a disposição de alinhar as pessoas aos modelos adotados na empresa.

“E como vencer as resistências, bom (...) as pessoas permanecem que ainda tem alguma dificuldade é... nós estamos trabalhando a nível gerencial, ... gerenciais tentando fazer com que os chefes de seção eles se alinhem a esse modelo né, então seria a primeira parte do treinamento por que a mudança ela não é... rápida ela é continua e agente faz em modelagem (...)” R4

Quando o respondente R1 narra que tem “notícias de resistências iniciais, que trabalhamos e depois a coisa anda" significa que a gestão de pessoas mediará, não de forma financeira, mas evocando a sedução na perfeita acepção do que foi dito por Enriquez (1991, apud SIQUEIRA, 2006) quando afirma que esta reside na aparência agradável. Nada mais agradável do ouvir que 'você vai ser mais feliz, vai trabalhar melhor e vai estar mais motivado', que será reconhecido pelo seu desempenho melhorado, que terá ganhos pessoais e profissionais.

A própria afirmação de que não haverá resistências é uma forma de banalizar esse problema, desqualificando um problema tão real, negando uma situação presente no diaa-dia de todas as empresas que pretendem a mudança. Na fala a seguir, percebe-se que, de fato, a resistência existe e é por parte de todos. 
"por completas (resistências) qualquer mudança, qualquer inovação, qualquer questão de mudança acho que de forma geral, no serviço público pela cultura que ele tem de perpetuidade (...) existem dificuldades e barreiras, as pessoas, qualquer, do mais baixo, do faxineiro ao presidente, ele resiste.” R3

A sedução está bastante presente nesse discurso. Segundo Freitas (2000 apud SIQUEIRA, 2006), a sedução é um convite a um mundo perfeito em beleza, em charme, em troca de emoções prazerosas, enfim uma magia e encanto, e se o indivíduo aceitar o convite, “pagar pra ver”, não vai querer mais voltar dessa ilha da fantasia e destruirá o elo que o ligava ao passado imperfeito.

Por trás do discurso da sedução, além de a empresa investir pesado no alinhamento da pessoa, através da doutrinação que, segundo Segnini (1996 apud SIQUEIRA, 2006), é o investimento na formação de trabalhadores doces, que não questionam a realidade à sua volta e, acima de tudo, produtivos e de baixo custo.

“...dotei esse profissional daquelas (competências) que ele precisava mais e ele tá no lugar certo, isso significa o seguinte: ele trabalha mais motivado, trabalha mais feliz, ele trabalha sem olhar para o relógio, em vez dele dar oito horas ele dá dez, ele nem percebe que ele tá dando dez, entendeu e obviamente, claro você tem um ganho na produtividade que faz muito mais com muito menos” R1

Após estar seduzida, a pessoa “em vez de dar oito, dá dez”, a empresa ganha sem precisar recompensar, pois ele nem percebeu que trabalhou a mais, não se questionou por que está trabalhando além do horário, que poderia estar em casa; com isso, passa a ser o superexecutivo de sucesso. Essa fala mostra claramente o que as empresas querem, antes de qualquer coisa: pessoas que se dediquem integralmente, que nem percebam o mundo à sua volta e que sejam obstinadas pelo sucesso.

A seguir uma outra conseqüência que os servidores estão sofrendo bastante e é bem retratada na fala do respondente, quando se refere às transformações que estão ocorrendo e que ocorrerão com a implantação do modelo gerencial na gestão pública.

“trazer reflexões na postura gerencial né, quer dizer aquele gerente que acha que ele é... ele desempenha bem o papel dele simplesmente cumprindo aquilo que tá previsto em termos de atribuições de cargos que ele ocupa, eu acho que essa (mudança para o modelo gerencial) trouxe essas reflexões, cumprir exatamente aquilo que tá definido no cargo não é suficiente, a pessoa tem que tá mais atenta....não simplesmente focar na descrição do cargo e se preocupar unicamente em desempenhar aquelas atividades, e sim pelo olhar mais amplo de aproveitamento de conhecimento dela pra agregar valor na instituição.” R2 
Na verdade, vemos aqui que o contrato de trabalho é uma mera peça de ficção. No caso do servidor público no Brasil o Regime Jurídico Único que traz todos os direitos, deveres, obrigações, proibições, penalidades e, principalmente, um modelo de conduta a ser seguido.

Podemos observar claramente pela narrativa acima que o funcionário público atualmente é obrigado a ir além do estipulado em seu contrato de trabalho. Ele não pode mais se restringir a cumprir, mesmo que bem feito, suas obrigações; ele precisa doar mais, precisa se exceder ao contrato que a própria administração aprovou em lei e lhe impôs ao assumir o seu cargo público.

Fica novamente clara a presença do discurso do superexecutivo de sucesso nas repartições públicas, já que o gerente público precisa ir além do estabelecido em Lei - e o que é pior, a nosso ver, precisa adivinhar o que a organização espera dele, haja vista não está claro nem explícito. Há bem pouco tempo, o trabalhador em geral sabia exatamente o que dele era esperado; agora, como só tem noção do que seja, excede-se sempre mais e mais em dedicação e em horário de trabalho para satisfazer à organização e agradar a chefia. O céu ou o inferno são os limites.

$\mathrm{Na}$ fala anterior, podemos também notar o discurso do comprometimento organizacional, ou melhor, uma cobrança para que o indivíduo se comprometa mais com a organização: “(...) a pessoa tem que tá mais atenta não simplesmente focar na descrição do cargo e se preocupar unicamente em desempenhar aquelas atividades, e sim pelo olhar mais amplo de aproveitamento de conhecimento dela pra agregar valor na instituição.” R2

Apela-se, aqui, para que a pessoa seja mais atenta, que dê mais de si para a organização, que use seus conhecimentos todos, não só os exigidos do cargo, em prol dos objetivos da empresa. Agregar valor para a empresa é a finalidade.

Nessa fala tenta-se chamar o funcionário para a responsabilidade que dele se espera, que ele se identifique com os objetivos da organização, que para Faria e Barbosa (2007), é o vínculo criado pela identificação e aceitação subjetiva das normas, valores e padrões estabelecidos como seus.

A nosso ver, nessa narrativa a própria pessoa já internalizou e já faz parte de seu imaginário, como uma exigência atual e legítima da organização, este estar “(...) mais atenta e o olhar mais amplo de aproveitamento de conhecimento (...)” dela, pois hoje somos obrigados a nos doar mais que o previsto no cargo. 
Das narrativas retro, acreditamos que, dentre outros, temos o discurso do superexecutivo de sucesso com maior intensidade. Apenas para ratificar nossa opinião, observemos a seguinte fala:

“(...) é um modelo (gerencialismo) centrado na atuação dos gestores né... colocando eles como responsáveis e como foco da gestão pública (...), e hoje tem um foco muito grande nas ações dos gestores.(...) mas também trouxe um ônus muito grande para os gestores né, então dá impressão que ser gestor é ser alguém superior às outras pessoas, por que ele é mais, ele precisa ter... ele precisa ser mais honesto, mais legítimo, mais organizado, mais tudo.” R3

Não resta a menor dúvida de que quando ouvimos falar “executivo”, gerente, gestor parece emergir um sentimento de superioridade que se encaixa naquilo que Chanlat (2002) se referiu ao afirmar que a vida cotidiana atual é totalmente influenciada pelo mito que o “executivo” proporciona. Paula (2005) nos diz que uma das crenças do modelo gerencialista está no fato de que o os gerentes têm o direito de administrar. Eles não podem nem devem ser impedidos de realizar seus trabalhos, haja vista eles serem "mais”, como na fala anterior.

As empresas investem pesado nessa idéia mitológica de que os executivos são mais inteligentes, dinâmicos, espertos, mais tudo, justamente por residir nisto o poder de fazer indivíduos conforme as pretensões das organizações. Eles se sentirão tão honrados em fazer parte e serem lembrados que esquecerão o resto. O resto, nesse caso, é a família, os filhos, os amigos, com exceção dos amigos dentro do círculo de influência da empresa. Além disso, se esquecerão da saúde, da ética etc.

O que ele busca é uma carreira e status profissional, que passa a ser o sentido de sua vida. A auto-imagem e o reconhecimento preencherão o seu desejo de sucesso (FRETAS, 2000). Segundo Pagès et. al (1993), o dinheiro é apenas mais um item que importa. O ser reconhecido é mais. O desejo agora é psicológico, e não material.

Como afirma Enriquez (2000, apud SIQUEIRA, 2006), nesse momento, não é mais permitido ao indivíduo perder, ele tem que ser um ganhador nato, um herói. Um guerreiro, disposto a tudo para conseguir seu objetivo.

Voltando à narrativa vemos a seguinte passagem:

“...mas também trouxe um ônus muito grande para os gestores né...”

Esse ônus, segundo Pagès et. al (1993, p. 133), seria ter de administrar a “contradição entre uma carga de trabalho opressiva, uma tensão permanente, pressões importantes; de outro, de seus desejos de liberdade e autonomia (...) pois o desejo de vencer o leva a trabalhar sempre mais e melhor”. Veja, o gestor tem que ser sempre o mais e o melhor. 
Felizmente a flexibilização da estabilidade do servidor público, pretendida pelos defensores do modelo gerencial, não logrou êxito ainda, senão os servidores sofreriam as mesmas conseqüências que os executivos da iniciativa privada sofrem.

Os superexecutivos de sucesso, quando não servem mais, estão ultrapassados, ou simplesmente não conseguem mais imprimir um ritmo de trabalho eletrizante, são aposentados ou demitidos. Nesse momento, se vêem sofrendo pela perda do poder e do status (SIQUEIRA, 2006). No caso do servidor público, ele sofre pela perda da posição, não podendo ser demitido em função da idade e fica encostado num canto, o que não reduz seus sofrimentos, uma vez que o poder enebria e seu possuidor não quer dele se apartar (ENRIQUEZ, 1991, apud SIQUEIRA, 2006).

Nesse contexto de reforma do aparelho do Estado e dos discursos em gestão de pessoas, os modismos gerenciais se destacam no incentivo propiciado pelas pessoas que buscam implantar o modelo gerencial no serviço público.

O "modismo gerencial" é uma forma de pressionar as entidades a serem eficientes, buscando a excelência e o sucesso na gestão pública. A qualidade total e a reengenharia são condicionadas para a pressão pela eficiência, excelência e sucesso. A administração da qualidade total e reengenharia, o downsizing, empowerment, gestão de desempenho, modelos de excelência, balanced scorecard, entre outros, são exemplos (CALGARO, SIQUEIRA, 2008).

Em diversas ocasiões, vemos narrativas que evocam ferramentas caracterizadas como modismos gerenciais: gestão por competências, qualidade total, benchmarking, entre outros. A seguir discutiremos essas modalidades.

A gestão por competências foi bastante lembrada pelos nossos entrevistados, talvez até por ter tido, no âmbito da instituição, uma experiência recente, que, para Faria e Leal (2007), é um movimento que alinha a inteligência das pessoas aos objetivos das organizações.

“(...) por exemplo, falando especificamente de gestão de pessoas: você precisa deslocar o eixo da capacitação não mais para necessidade do servidor, mas para necessidade da instituição, havia isso na administração pública, 'que curso você quer fazer?' 'Há eu quero fazer de não sei o que, tarará, tarará. Não, hoje não é mais assim, primeiro que você precisa otimizar investimento, segundo que você precisa ir ao alvo, o que a organização precisa em termos de competência instalada no colaborador”. R1

“nós fomos a todas as unidades do (...) fazer o levantamento de necessidade de capacitação, mas não é a nível pessoal, o que o gerente quer, o que o servidor quer tá, e o levantamento de 
necessidade de capacitação pra desenvolver pessoas para o negócio da unidade, para alcançar resultados, entendeu? que obviamente se agente trabalha com esse, focado no negócio das unidades” R3

Nessas falas, notamos que, de fato, está acontecendo uma mudança no foco da capacitação. Pela narrativa, há pouco tempo a capacitação se guiava pelo interesse pessoal do servidor, não guardando necessariamente ligação entre o objeto e o treinamento à realização do trabalho. Apenas reafirmando, agora a área de treinamento está focada no negócio da unidade.

O próprio respondente já indica por que isso está acontecendo. Mais um reflexo da crise fiscal do Estado, que, sem recursos, tem procurado investir melhor, e buscar a correspondência entre o gasto com o investimento é o retorno que ele proporcionará.

Continuando nessa fala, não percebemos ainda que institucionalmente houve, pelo menos no discurso, a transferência da responsabilidade em se gerir a carreira ou se autodesenvolver - o que é bastante positivo. Segundo Faria e Leal (2007), um dos motivos que leva a empresa a implantar a gestão por competências é transferir essa responsabilidade para o indivíduo que, além de baratear os custos com cursos e ausências no expediente para realizá-los, está o fato de legitimar possíveis decisões de punições por não alcançar a competência necessária.

Quando a empresa assume essa responsabilidade, precisa controlar todo o processo; se por um lado é bom; por outro, a organização limita os conteúdos ao seu interesse.

Para completar essa análise, segue a outra fala:

“Na verdade uma organização gera resultado através das pessoas, por intermédio das pessoas. Então você precisa trazer as pessoas certas, colocá-las nos lugares certos e desenvolver essas pessoas para que a empresa gere resultado através delas.” R1

A princípio, temos aqui que, de fato, a organização pesquisada assume a responsabilidade pelo desenvolvimento das pessoas. Mas também não esquece e dá ênfase que precisa das pessoas, porque são elas que geram resultados para a empresa. Logo, investe no desenvolvimento unicamente profissional. Na fala anterior, temos a afirmação de que o interesse é exclusivo no que a empresa precisa, e não no que a pessoa quer.

Na resposta a seguir, percebemos mais uma forma utilizada para comprometer e motivar os empregados:

“...dotei esse profissional daquelas (competências) que ele precisava mais e ele tá no lugar certo, isso significa o seguinte: ele trabalha mais motivado, trabalha mais feliz, ele trabalha sem olhar para o relógio, em vez dele dar oito horas ele dá dez, ele nem percebe que ele tá 
dando dez, entendeu, e obviamente, claro você tem um ganho na produtividade que saiu muito mais com muito menos...” R1

Por essa fala, a pessoa deve ficar feliz, pois foi dotada das competências que a empresa precisa que o indivíduo tenha para que ela mesma, a empresa, tenha ganho em produtividade, porque a pessoa foi lotada no lugar certo.

Notamos que a empresa toma todas as decisões e ações pensando em vantagens únicas para si e, mesmo assim, investe em um discurso de que é bom para os empregados. Estes devem ficar felizes e trabalhar mais. Será que a pessoa quer aquele lugar imaginado pela gestão de pessoas como certo?

Outra ferramenta citada pelos respondentes foi o ciclo do PDCA, o que não é de se estranhar haja vista que os técnicos do Mare recomendam o seu uso.

"essa filosofia tá, utilizando o método também que é uma ferramenta da administração pela qualidade que é o PDCA, da própria estrutura interna que agente tá mudando, (...) essa mudança ela tá dentro dessa filosofia né, então a pessoa que elas passam a ter seu próprio... mudar e a trabalhar de acordo com método que ele quer, planejar cada um faz o seu né, faz o seu planejamento... faz o seu... elabora o seu... suas tarefas, como vai fazer a operacionalização disso, vai operacionalizar, vai avaliar e vai corrigir o que foi identificado (...) isso vai refletir também como modelo para a instituição, por que à medida que outras autoridades dentro da instituição perceberem como tá funcionando, e tá funcionando bem eles, também querem.” R4

Nessa narrativa, notamos dois aspectos bem peculiares. Primeiro, o ciclo PDCA que, nesse caso específico, nos parece que aumentará a autonomia dos servidores já que eles “(...) passam a ter seu próprio... mudar e a trabalhar de acordo com método que ele quer, planejar cada um faz o seu né, faz o seu planejamento... faz o seu... elabora o seu... suas tarefas, como vai fazer a operacionalização disso, vai operacionalizar, vai avaliar e vai corrigir o que foi identificado...”. Seria bom se, de fato, a autonomia viesse, mas, como dizem Chanlat (2002) e Enriquez (1997a), vivemos um paradoxo entre a hierarquia e autonomia, e com muito mais responsabilização.

Segundo, o respondente projeta que, caso a mudança implementada funcione, servirá de modelo e, a partir disso, outra ferramenta do modelo gerencial será posta em prática, o benchmarking interno na instituição, que as autoridades passaram a aplicar.

“(...) isso vai refletir também como modelo para a instituição, por que à medida que outras autoridades dentro da instituição perceberem como tá funcionando, e tá funcionando bem eles, também querem.” R4 
Benchmarking, processo pelo qual uma empresa busca junto à concorrência, aos fornecedores e aos parceiros as melhores práticas de gestão e produção visando à maximização de desempenho empresarial, está sendo bastante incentivado. Marini (2002) inclusive nos diz que um dos principais métodos para o desenvolvimento empresarial reside nesse intercâmbio de experiências institucionais. Continua afirmando que o Benchmarking é típico de empresas privadas e atualmente utilizado no setor público, além de recomendado como forma de ganho de eficiência. O Poder Judiciário não escapa desse processo de modernização vislumbrado pelas melhores práticas.

“(...) tem uma fundamentação teórica nos modelos é... privado, embora quando você traz essa nossa realidade pública, é feita toda uma adequação, não tem como você pegar né, não conheço nenhuma prática que tenha vindo para o STJ exatamente como ela é aplicada no mundo privado né, e a gestão por competência que também é um modelo que é salutar, muito praticado nas empresas privadas, essa gestão por competência no serviço público é... também foi tentada aplicar exatamente como ela é adotada no setor privado e ela não vingou, quer dizer há a necessidade de adequar o modelo à realidade pública.” R2

Nessa narrativa, o respondente deixa claras as preocupações que devemos ter antes de aplicar o benchmarking ao tentar aplicar uma ferramenta da iniciativa privada adotando tal como é aplicado lá. Indica, inclusive, uma prática que não vingou, em suas palavras, quando foi trazida tal qual para o universo público.

Talvez uma reflexão profunda antes de implementar evitasse desgastes como deve ter ocorrido nesse caso. Estamos falando em reflexão, que seria estudar, analisar conceitos, verificar possíveis adequações e vislumbrar, no cenário interno, se será útil e salutar sua implantação.

Não estamos falando em customizar, que seria apenas adequá-las para a empresa. Note-se, o contexto privado é muito diferente do contexto público; por isso, requer muita reflexão, e não apenas adequação.

Nesse aspecto, outra prática que vem sendo objeto de benchmarking é a qualidade total.

“em administração pela qualidade, então essa filosofia de administração ela é inteiramente viável para implementação no STJ e no ambiente público. É uma filosofia de administração que precisa também envolver as autoridades, obvio né, no caso o STJ as autoridades do STJ e da sociedade, as autoridades governamentais.” R4

Outro modismo gerencial recomendado para o serviço público é a administração da qualidade total (TQM), inclusive na análise da entrevista retro "essa 
filosofia de administração ela é inteiramente viável para implementação no STJ e no ambiente público”.

Filosoficamente, a administração da qualidade total é de origem japonesa e tinha algumas características que, infelizmente, a nosso ver, não se adéquam à filosofia que o modelo gerencial quer trazer para as empresas públicas.

A reforma gerencial quer flexibilizar as relações de emprego, acabando com a estabilidade e vitaliciedade dos funcionários em seus cargos e funções, que, ao entender de Paula (2005), são características da sociedade e das empresas japonesas. Outra característica peculiar daquela sociedade é o fato de a empresa ser interpretada como uma família. No Brasil, tanto o modelo burocrático quanto o modelo gerencial tentam atacar o patrimonialismo. Será que essa característica seria usada de forma saudável ou apenas seria mais uma forma para justificar o nepotismo?

Acerca da TQM, alguns autores, dentre eles Paula (2005) citando Collins (2000) afirma que esta nada mais é que uma administração ambígua incentivando uma eficiência e melhora contínua, visando apenas aumentar o controle e a disciplina dos trabalhadores.

Por fim, no nosso entender, na questão da qualidade devemos refletir bastante acerca da sua implantação no serviço público. Não que não devamos procurar melhorar sempre o nosso desempenho e procurar meios para melhorar o desempenho de todos, mas sempre precedido de uma análise cuidadosa. Será que, de fato, podemos conseguir a melhora de desempenho na esfera pública com a TQM e ao mesmo tempo progredir em condições de trabalho?

Outro crítico da TQM, Gaulejac (2007), afirma que a idéia da qualidade é posta em círculos como em uma equação que, para ele, é mágica: em círculos, pois não tem fim, e mágica, já que não existe a qualidade total, assim como não existe um mundo de pureza, um mundo sem defeito, onde todos realizarão suas tarefas sempre de forma perfeita.

Com relações à condição de trabalho, será que com a implantação do gerencialismo, via ferramentas gerenciais, as condições de trabalho irão ou estão se degradando na entidade pesquisada?

"eu acho que se não tiver cuidado pode até piorar (as condições de trabalho) e eu acho que pode até ter um acréscimo em termos de stress, e se não tiver também um cuidado” R2 "trabalhando pressionado por resultados, se elas são pressionadas no emocional e não no trabalho braçal, elas adoecem, eu conheço pessoas assim, eu já conheço pessoas que basta 
pressionar com trabalho, pelo menos tem notícias, pessoas que você se começou a pressionar pelo o trabalho elas já adoecem.” R3

Chanlat (2002) já apontara que as condições de trabalho dos servidores públicos estavam se degradando devido à transição do modelo burocrático para o modelo gerencial. Para o autor, a diminuição do contingente de funcionários públicos devido à crise fiscal do Estado e a entrada de novos indicadores de desempenho provocaram uma pressão maior sobre os servidores remanescentes.

Interessante mencionar que apenas nessas duas falas notamos preocupação com a questão de saúde dos servidores, pelo menos diretamente. Esses entrevistados mostraram preocupação com a possível causa de doenças, levando-nos a pensar que o modelo gerencial ainda não evolui na organização a ponto de causar doenças ou a entidade já cuida para que tais doenças não atrapalhem o rendimento.

Quando falamos em transição, falamos nas mudanças que advirão conforme relatado abaixo.

“a vantagem que eu vejo no serviço público é que você não sofre uma pressão tão grande quanto na empresa privada, imagino que se agente sofre por pressão agente não tem noção do que é pressão, por que pressão sim sofre quem tá em uma empresa privada onde o dia-adia é o que mantém ou tira ele daquele lugar, e se ele sair daquele lugar ele é, ... vai pra rua” R3

Nessa narrativa, fica clara a diferença da pressão exercida em um ambiente público, em que a flexibilização da estabilidade ainda não aconteceu. Quando acontecer, provavelmente as portas do serviço público estarão abertas para os fisiologismos, nepotismo, troca de favores e ameaças baseadas em interesses escusos, além do que já existe.

Para nós, então, não é surpresa a piora das condições de trabalho. Surpresa sim reside no fato de se negar o aumento da pressão ou a transferência da pressão como se partisse do próprio servidor.

“não a pressão, ela não aumenta, na verdade o que muitas vezes aumenta é a própria expectativa do colaborador em relação a melhorar o desempenho dele tá, não aumenta a pressão pelo resultado, pelo contrário o resultado sai com muito mais fluência” R1

“não, (pressão por resultado) vai continuar apenas o que já é hoje, apenas as pessoas vão... vão... é um processo bem transparente todos vão observar que os resultados com maior facilidade.” R4

"quer dizer, no mesmo tempo de trabalho você tem que aumentar a quantidade, e às vezes o que acontece, a pessoa não se sente preparada, agora pra dar o retorno que tá sendo exigido, 
então ela acha que ela tem que aumentar a jornada de trabalho dela pra poder conseguir dar o retorno que tá sendo esperado, então aumenta a jornada de trabalho pra aumentar a produtividade, enquanto que o correto ou o que deveria ocorrer e preparar esse profissional, esse servidor pra que naquela mesma jornada ele consiga produzir mais e melhor.” R2

Nas duas primeiras narrativas percebemos a negação de que haverá aumento na pressão por resultados e, em seguida, na primeira, acontece a transferência da responsabilidade como nos moldes da gestão de competência, que transferiu a responsabilidade de treinar das empresas para o "se desenvolver" dos empregados e talvez a negação pela sedução, ou seja, minimizar um problema, suavizá-lo.

Na terceira narrativa, vemos como os funcionários pressionados se viram para dar conta dos novos patamares de produtividade que, conforme Chanlat (2002), foram trazidos pelo mercado.

Corroborando essa idéia, vejamos as falas a seguir.

“aumentou (pressão por resultados). Eu acho que os servidores hoje é... ele já tem uma preocupação em estar sendo bem avaliado pela sua chefia, pela casa. Ele já tem um cuidado maior com a sua carreira enquanto profissional” R2

“eu acredito que é (a pressão)- vem dos dois lados (do servidor e da organização) tanto na questão das mudanças né, formação e assim as exigências mesmo do mercado de trabalho no setor privado, essa pressão do setor privado hoje agente verifica um pouco dessa pressão no setor público. E o servidor é... a cultura organizacional eu percebo que tá tendo essa mudança. O servidor tem procurado mais se profissionalizar né, de estar é... conhecendo novas tecnologias, novas práticas que faça que seu trabalho seja melhor reconhecido né, eu acho não só pela preocupação de produzir mais pra empresa, mas eu acho de uma questão pessoal dele se sentir um melhor profissional.” R2

Novamente, utilizaremos Chanlat (2002), quando este afirma que nos últimos 20 anos os servidores públicos sofreram bastante com a campanha para denegrir a imagem da categoria.

Faria, Schimit e Meneguetti (2.007) afirmam que o reconhecimento e a aceitação social são uns dos elementos centrais de suas vidas. Provavelmente hoje em busca de reverter essa impressão, estejam se desdobrando e tentando provar sua capacidade e novamente conquistar a aceitação social.

“por que provavelmente há pessoas, e através delas você consegue resultado, as pessoas vão trabalhar mais motivadas, elas têm que ter a contra partida da organização em termos de reconhecimento....não é venha a nós, venha a nós e vosso reino nada não: é uma troca...... eu 
te reconheço e te dou condições, mas em compensação me gere resultados, é uma troca, aliás tudo na vida é uma troca." R1

Nesta fala, percebe-se que o entrevistado dá a devida importância às pessoas, pois sabe que é através delas que a organização consegue os resultados.

Como já falado, a gestão de pessoas não funciona apenas como mediadora econômica funciona também para fazer com que as pessoas, os servidores sejam conformes à organização e adiram aos seus objetivos. Nesse aspecto, os servidores públicos, buscando a aceitação social perdida nos últimos vinte anos, se tornariam presas fáceis e estariam a um passo de se tornarem os novos superexecutivos de sucesso, pois dentre as características deste está o reconhecimento como fator principal.

“...elas têm que ter a contra partida da organização em termos de reconhecimento (...) eu te reconheço e te dou condições, mas em compensação me gere resultados...” R1

Por essa narrativa, a gestão de pessoas está ciente das necessidades de reconhecimento dos servidores públicos.

Dentro da ótica de se buscar a aceitação, os indivíduos buscam fazer mais e melhor. Na narrativa a seguir, o respondente notou se tratar de um traço da cultura da organização uma espécie de neurose pelo "tudo muito 'certinho' todo mundo que as coisas direitinho”, senão vejamos:

“o perfeccionismo é uma característica do órgão é engraçado que eu vejo em todas as pessoas, alguns têm mais, outros têm menos, uns destoam, mas é a exceção, a maioria quer... tem esse mesmo aspecto, tudo muito 'certinho' todo mundo quer as coisas direitinho (...) é um traço cultural (da organização).” R2

Parece novamente que os servidores públicos estão, de fato, se desdobrando para, além de cumprir seus deveres, provarem algo.

Nesse caso, temos talvez o que Aubert (1993) descreveu como neurose de excelência, haja vista que ela poderia se manifestar em profissionais que buscam um ideal profissional muito elevado; porém, pela fala, podemos perceber que se trata de algo generalizado em toda organização, “(...) alguns tem mais outros tem menos, uns destoam, mas é a exceção, a maioria quer... tem esse mesmo aspecto (...)” e não um caso isolado.

“Em primeiro lugar agente... agente... no início as pessoas estranham, resistem, depois elas vão se alinhando, e depois que elas vêem que agente tá plantando excelentes resultados, nós vamos trabalhar no nível de excelência de atendimento ao cliente inclusive, essa ligação de eventos é... a própria equipe vai passar a entender que isso é um fator motivador” R4 
Por falar em excelência, vemos também que ela é incentivada pela gestão de pessoas “(...) nós vamos trabalhar no nível de excelência (...)”. Para Gaulejac (2007), faz parte das atribuições da gestão de pessoas incutir nos indivíduos que existe erro zero, que existe herói, que seria possível que todos os trabalhos pudessem ser efetuados de forma equânime e perfeita, o que provocaria, segundo Aubert (1993), processos neuróticos, como esse que, segundo o relato, se tornou cultural na instituição.

Outra busca do servidor, ou melhor, outra forma de se pressionar os servidores seria a autonomia, que, segundo Chanlat (2002), seria uma tendência aumentar a responsabilidade e imputação destes sem a devida autonomia.

“O gestor na empresa pública, no órgão público ele não tem autonomia, como tem um gestor. O gestor na empresa privada ele tem condições de dizer e definir quem ele vai captar, quanto ele vai gastar, como ele vai distribuir esse orçamento entre as pessoas, quanto ele vai gastar em capacitação e com material, e com isso e com aquilo, o que ele vai botar o que ele vai tirar, se ele precisa de alguém ele vai ao mercado e busca, se ele quiser vender a empresa... ele tem essa autonomia” R3

"é muito mais complexo administrar dentro do serviço público, sem equipamento, sem autonomia por que às vezes ele não tem autonomia...” R3

Por essas narrativas, podemos perceber que os gestores de empresas públicas carecem de autonomia para realizarem seus trabalhos. Ao contrário, os respondentes acreditam que na iniciativa privada ela exista.

Enriquez (1997a), pelo contrário, acredita que isso seja um mal que não atinge apenas os servidores públicos, mas também o trabalhador da iniciativa privada. O autor afirma que o indivíduo nunca esteve tão inserido no mundo organizacional e que já perdeu a liberdade de seu corpo, alma e psique.

Voltando à autonomia, Chanlat (2002) afirma que, apesar do gerencialismo, a hierarquia no serviço público continua do mesmo modo, o que provocaria contradições e incoerências. O indivíduo é responsabilizado pelo que faz, sem ao menos decidir como fazêlo. Pelo contrário, de acordo Enriquez (1997b), o trabalhador, quando é nomeado responsável, é obrigado a prestar contas de seus atos perante os superiores que o vêem como suspeito e um provável culpado. 


\section{5 - CONCLUSÃO}

A influência que o modelo gerencial e o gerencialismo exercem sobre a instituição pesquisada ficou latente diante dos relatos. O modelo gerencial se caracteriza pela tentativa de tornar mais "gerencial” a administração pública. O gerencialismo seria o excesso de utilização dessas ferramentas. A própria cultura do management.

Pode-se notar ser difícil essa separação justamente por eles, pelo menos na mídia, virem sempre juntos, e quanto se fala em modelo gerencial, cultura do management, o gerencialismo, vem a seguir com suas ferramentas milagrosas.

O fato é que a influência do modelo gerencial é enorme nas pessoas da Instituição pesquisada. Tanto na análise das entrevistas, tanto em folders e na rede interna de computadores, identificamos a presença de várias ferramentas do modelo gerencial: Melhores empresas para se trabalhar, gestão por competências, benchmarking, melhores práticas, comprometimento, educação coorporativa.

Vários discursos em gestão de pessoas aos moldes da iniciativa também foram identificados, objeto principal de nossa pesquisa. Além de perceber como os servidores estão sentindo essa transição de um modelo burocrático para um modelo gerencial.

A primeira categoria analisada tratava da transição da burocracia para o modelo gerencial na ótica dos gestores de pessoas. Nessa categoria ninguém tentou conceituar nem a burocracia nem o modelo gerencial. Focaram a questão prática e de como sentem as conseqüências negativas da burocracia para os servidores públicos e para o trabalho.

De uma forma geral, todos os respondentes analisaram a burocracia de forma negativa. Ela, além de atrapalhar o andamento do serviço, ainda serve para que os servidores se escondam atrás das normas, ou melhor, criam até normas para dificultar o andamento das tarefas. O fim da burocracia foi colocado como forma de melhorar o andamento dos trabalhos, seguindo os preceitos da reforma para o modelo gerencial proposto.

Também tivemos respondentes que, embora acreditando que a burocracia mais atrapalhe, entendem ser ela necessária para resguardar o controle.

Por fim, na narrativa de um respondente, foi colocada uma característica da burocracia, a meritocracia, como solução que melhoraria muito a administração. Nesse aspecto, não conseguimos captar se a pessoa tinha esse conhecimento, mas, de qualquer forma, notamos que todos os entrevistados dominam as particularidades de gerir no serviço público num ambiente burocrático. 
A segunda categoria buscava identificar a percepção dos gestores de pessoas acerca das diferenças e semelhanças em gerir pessoas em órgãos públicos e empresas privadas. Para nós, essa análise é muito importante, pois muitas ferramentas típicas do universo privado estão aí, sendo oferecidas por diversas consultorias como salvação do serviço público. Precisávamos saber até que ponto os gestores entendem a dicotomia entre o público e o privado.

Chanlat (2002) acredita ser temerário não distinguir uma da outra, o que foi ratificado pelos entrevistados ao afirmarem que quando estão atuando no serviço público a postura é distinta daquela na iniciativa privada - na gestão pública se administra para a coletividade.

Além da influência da indústria do management ao evocar a satisfação total do cliente e de que na proposta de reforma do aparelho do Estado, existe a intenção de transformar o cidadão em cidadão-cliente, observamos algumas narrativas que indicavam a mudança do foco no processo para o foco no cliente. Como bem colocado por Gaulejac (2007), isto é bastante temerário.

Talvez neste ponto resida a falha na questão sociopolítica do modelo gerencial descrita por Paula (2005), uma vez que afasta a responsabilidade e a possibilidade de o cidadão participar efetivamente das decisões e das políticas públicas.

Por fim, houve a afirmação de que é melhor gerir pessoas na iniciativa privada, apesar de lá a pressão ser maior. Na iniciativa privada, as pessoas não seriam tão resistentes e responderiam às mudanças com maior rapidez. Embora, a nosso ver, o que torna mais interessante administrar pessoas na esfera privada seja o fato de o servidor público ter ao seu lado o instituto da estabilidade, além, é claro, do fato de que a administração pública necessariamente ser mais democrática que as empresas particulares. A própria conceituação já nos remete a um ambiente mais restrito, a empresa “é particular”; logo, a gestão é efetuada ao gosto do proprietário.

As resistências, pressões, discursos organizacionais em gestão de pessoas bem como as conseqüências para as pessoas presentes na instituição pesquisada com viés do modelo gerencial foram a terceira categoria pesquisada. Optamos, em primeiro lugar, por verificar possíveis resistências às ferramentas desse modelo, justamente porque quando falarmos em resistências já apareceriam discursos defendendo ou não os reflexos e a atuação e a forma de mediação, tanto da gestão de pessoas quanto do servidor.

Ao falar em resistências, aparecem formas distintas de percebê-las no ambiente ao admitir que ela de fato exista no ambiente interno em relação às mudanças e sendo 
oferecidas por todas as pessoas, e ao admitir que exista apenas de forma inicial e que, em seguida, se transformará em comprometimento.

Notamos, nesse segundo caso, a presença da sedução em dois aspectos: quando diminui ou nega uma situação organizacional, a resistência, real e séria, que afeta todas as empresas públicas ou privadas em processo de mudança, e quando se faz o convite para a felicidade.

Podemos também perceber que de fato a gestão de pessoas, além de funcionar como mediadora econômica, também é requerida a atuar em situações de mudanças buscando a adesão às mesmas.

Vários discursos de organizações foram identificados nas falas.

O servidor da Instituição pesquisada está sendo objeto de investimento para se tornar um superexecutivo de sucesso. Pela sedução, já que está sendo convidado a ser feliz e, assim, produzir mais e trabalhar a mais sem perceber. Ao ser chamado pela responsabilidade e impelido a se comprometer com a instituição, e não se restringir apenas ao que o cargo pede, precisa se doar mais.

Nesse momento, o servidor está muito suscetível a esse discurso, ora por buscar a legitimação social perdida e ser alvo de críticas nos últimos 20 anos, ora pelo traço cultural de querer tudo certinho.

O discurso do comprometimento aparece no exato momento em que ele é inquirido a doar mais de si próprio, além do previsto legalmente nas atribuições do cargo. Exige que utilize todos os seus conhecimentos e um olhar mais amplo para agregar valor à instituição.

Os modismos gerenciais aparecem nas narrativas sob forma de diversas ferramentas. O benchmarking, a qualidade total, a gestão por competência e o ciclo do PDCA.

De acordo com Paula (2005), o modismo gerencial é uma forma de pressão para que as empresas melhorem a eficiência e os resultados.

Nesse contexto, na instituição pesquisada, a pressão sobre os servidores com as ferramentas já mostra suas facetas e conseqüências. Novamente aqui temos narrativas que reconhecem que pessoas estão sendo pressionadas, narrativas que mostram que não haverá aumento na pressão e narrativas que indicam que a pressão está aumentando em função de o próprio servidor querer aumentar a produtividade.

O próprio conceito de modismo gerencial já indica o aumento de pressão por produtividade; logo, não vislumbramos ser diferente na esfera pública essa pressão. Negar a 
pressão seria suavizá-la e utilizar o discurso da sedução. A pressão que vem do indivíduo sobre ele mesmo é possível, haja vista a cultura organizacional.

Dentro das seis modalidades de discursos organizacionais em gestão de pessoas definidos por Siqueira (2005), não nos foi possível identificar nas falas, pelo menos de forma clara, a existência dos seguintes discursos:

O discurso do ganhe em participação talvez não tenha sido citado, haja vista a impossibilidade, dentro da esfera pública e da instituição pesquisada, de se retribuir os servidores públicos nesses termos.

O discurso da saúde nas empresas não foi percebido. Algumas narrativas lembraram o tema da saúde, mas apenas no contexto das conseqüências que poderão advir do aumento da pressão, e não como um discurso organizacional.

Não foi lembrado o discurso das melhores empresas para se trabalhar, embora a instituição tenha efetuado inscrição para participação na seleção efetuada pela revista Exame no ano de 2008.

Acreditamos que nossa pesquisa conseguiu seus objetivos, na medida em conseguimos identificar o discurso organizacional em gestão de pessoas presente em uma organização pública federal à luz do crescente gerencialismo e dos novos patamares de desempenho requeridos dos mesmos.

Da mesma forma os objetivos específicos foram atendidos, uma vez que investigamos e detectamos a existência de ferramentas do modelo gerencial, identificamos e discutimos as conseqüências delas sobre os servidores e a reação destes frente à transição do modelo burocrático para o modelo gerencial, embora vislumbrássemo-la, a pesquisa precursora para provocar a reflexão e novos estudos na área.

Sabemos que existem poucas pesquisas relacionadas aos reflexos do modelo gerencial sobre os servidores públicos, por isso uma agenda que contemple esse tema seria de importância vital para a evolução da administração pública e para as condições de trabalho dessa categoria.

Por fim, queremos finalizar nosso estudo recorrendo à seguinte narrativa: "o único cuidado que eu acho que é importante se ter quando se fala na gestão de pessoas é que às vezes se tem um foco muito na questão da produtividade, na qualidade da produtividade, sem ter um olhar para a pessoa, eu acho que tem que ter a... antes de se cobrar esse aumento na quantidade, na qualidade você tem que ver a formação, como o 
servidor está né, o que precisa ser feito em termos de preparo pra... antes de se jogar em cima desse profissional exigências que o mercado tem demandado, só isso.”

Observe-se que, de fato, temos muitos indivíduos atentos às condições de trabalho do servidor. Nessa narrativa, a pessoa é bastante feliz e vai de encontro ao que acreditamos ser o ideal na gestão de pessoas, pois devemos ter bastante cuidado para não sermos tragados pela quantofrênia que assola o mercado.

Devemos procurar vantagens competitivas para as empresas e para as pessoas. Respeitar as subjetividades das pessoas. E buscar formar pessoas e cidadãos para construir uma relação de trabalho positiva e uma administração pública que, de fato, atenda aos anseios da população. 


\section{REFERÊNCIAS}

AUBERT, Nicole. A Neurose Profissional. Fundação Getúlio Vargas. Revista de Administração de Empresas. São Paulo, v. 33, n. 1, p. 84-105, jan./fev. 1993.

AZEVEDO, Clovis; LOUREIRO, Maria Rita. Carreiras Públicas em uma Ordem Democrática: Entre os Modelos Burocráticos e Gerenciais. Revista do Serviço Público, Brasília, v. 54 (1), p. 43-57, jan./mar. 2003.

CALGARO, Jose Cláudio Caldas; SIQUEIRA, Marcus Vinicius Soares. Servidão e Sedução: Duas Faces do Gerencialismo Contemporâneo. In: MENDES, Ana Magnó1ia (Org.). Trabalho e Saúde: O Sujeito entre a Emancipação e Servidão. 1ª Ed. Curitiba: Juruá, 2008. p. 115- 128.

CALGARO, Jose Cláudio Caldas. Influências do Gerencialismo nas Relações de Trabalho em uma Universidade Pública Federal. 54 f. Monografia Pós-Graduação em Gestão de Pessoas. Universidade de Brasília, 2007.

CHANLAT, Jean-François. O Gerencialismo e a ética do bem comum: a questão da motivação para o trabalho nos serviços públicos. In: VII Congresso Internacional del CLAD Sobre La Reforma Del Estado y de La Administración Pública, Lisboa: Anais. CLAD, 2002. P. 8-11.

DAVEL, Eduardo; VERGARA, Sylvia Constant. Gestão com Pessoas, Subjetividade, e Objetividade nas Organizações. In: Gestão Com Pessoas e Subjetividade. São Paulo: Atlas, 2008. p. 31-56.

ENRIQUEZ, Eugène. O indivíduo Preso na Armadilha da Estrutura Estratégica. Fundação Getúlio Vargas. Revista de Administração de Empresas. São Paulo, v. 37, n. 1, p. 18-29, jan./mar. 1997a.

Os desafios Éticos nas Organizações Modernas. Fundação Getúlio Vargas. Revista de Administração de Empresas. São Paulo, v. 37, n. 2, p 6-17, abr./jun. 1997b.

FARIA, José Henrique. Os Fundamentos da Teoria Crítica: Uma Introdução. In: FARIA, José Henrique (Org.). Análise Crítica das Teorias e Práticas Organizacionais. São Paulo: Atlas, 2007. p. 1-20.

FARIA, José Henrique; SCHIMITT, Elaine Cristina. Indivíduo, Vínculo e Subjetividade. In: FARIA, Jose Henrique (Org.). Análise Crítica das Teorias e Práticas Organizacionais. São Paulo: Atlas, 2007. p. 23-44.

FARIA, José Henrique. MENEGHETTI, Francis Kanashiro. O Seqüestro da Subjetividade. in: FARIA, Jose Henrique (Org.). Análise Crítica das Teorias e Práticas Organizacionais. São Paulo: Atlas, 2007. p. 44-67.

FARIA, José Henrique; SCHIMITT, Elaine Cristina; MENEGHETTI, Francis Kanashiro. O Imaginário Vigiado nas Relações de Trabalho. In: FARIA, Jose Henrique (Org.). Análise Crítica das Teorias e Práticas Organizacionais. São Paulo: Atlas, 2007. p. 68-91. 
FARIA, José Henrique; BARBOSA, Solange de Lima. Comprometimento: uma Avaliação Crítica Sobre a Práxis Organizacional. In: FARIA, Jose Henrique (Org.). Análise Crítica das Teorias e Práticas Organizacionais. São Paulo: Atlas, 2007. p. 92-114.

FARIA, José Henrique; MENEGHETTI, Francis Kanashiro. Discursos Organizacionais. In: FARIA, Jose Henrique (Org.). Análise Crítica das Teorias e Práticas Organizacionais. São Paulo: Atlas, 2007. p. 117-141.

FARIA, José Henrique; OLIVEIRA, Sydnei Nilton. Gestão da Qualidade, Subjetividade e Desempenho Organizacional. In: FARIA, José Henrique (Org.). Análise Crítica das Teorias e Práticas Organizacionais. São Paulo: Atlas, 2007. p. 190-202.

FARIA, José Henrique; LEAL, Anne Pinheiro. A Gestão por Competência no Quadro da Hegemonia.In: FARIA, José Henrique (Org.). Análises Crítica das Teorias e Práticas Organizacionais. São Paulo: Atlas, 2007. p. 142-166.

FREITAS, Maria Éster. A moda que Não e Mais Moda. Fundação Getúlio Vargas. Revista de Administração de Empresas. RAE Eletrônica. São Paulo, v 5, n. 1, Resenha 1, jan./jun. 2006.

Contexto Social e Imaginário Organizacional Moderno. Fundação Getúlio Vargas. Revista de Administração de Empresas. São Paulo, v. 40, n. 2, p 6-15, abr./jun. 2000.

GAULEJAC, Vincent de. Gestão como Doença Social. Ideologia, Poder Gerencialista e fragmentação Social. Aparecida, SP: Idéias e Letras, 2007.

MARINI, Caio. O Contexto Contemporâneo da Administração Pública na América Latina. Revista do Serviço Público, Brasília, 53 (4), p 31-52, out./dez. 2002.

MATOS, Fátima Regina Ney; LIMA, Afonso Carneiro. Organizações Modernas e a Burocracia: Uma a "Afinidade Eletiva?". Fundação Getúlio Vargas. Revista de Administração de Empresas. RAE Eletrônica. São Paulo, v. 6, n. 2, Art., 14. jul./dez. 2007.

MENDES, Ana Magnó1ia. Pesquisa em Psicodinâmica: A Clínica do Trabalho. In: MENDES, Ana Magnó1ia, et. al. Psicodinâmica da Teoria: Teoria, Método e Pesquisa. São Paulo: Casa do Psicó1ogo, 2007. p. 65-87.

PAGÈS, Max, et. al. O poder das Organizações. $3^{\text {a }}$ ed. São Paulo: Atlas, 1993.

PAULA, Ana Paula Paes de. Por Uma Nova Gestão Pública: Limites e Potencialidades da Experiência da Contemporânea. Rio de Janeiro: Editora FGV, 2005.

SIQUEIRA, Marcus Vinicius S. Gestão de Pessoas e Discurso Organizacional: Crítica a Relação Indivíduo-Empresa nas Organizações Contemporâneas. Goiânia: Ed. da UCG, 2006.

RENAUlT, Sergio Rabello. A reforma do Poder Judiciário sob a Ótica do Governo Federal. Revista do Serviço Público, Brasília, 56 (2), p. 127-136, abr./jun. 2005. 
VERGARA, Sylvia Constant. Começando a definir a metodologia. In: Projetos e

Relatórios de Pesquisa em Administração. $3^{\mathrm{a}}$ ed. São Paulo: Atlas, 2000. Cap. 4, p. 46-53.

VERGARA, Sylvia Constant. Gestão de Pessoas. $3^{\text {a }}$ ed. São Paulo: Atlas, 2003. 